\title{
Normative Canons in the Review of Administrative Policymaking
}

\begin{abstract}
AB STR ACT. Who should ensure that statutes are interpreted to reflect background norms left unaddressed by Congress - norms like respect for the rights of regulated parties, protection of the interests of states and Native American tribes, avoidance of government bias, and the separation of powers? On the one hand, courts have traditionally sought to protect these constitutionally inspired values by applying "normative" canons of construction. On the other hand, after the Supreme Court's Chevron decision, authority to interpret unclear regulatory statutes generally belongs not to judges, but to agencies. This question has polarized courts and commentators. A majority, including the Supreme Court, adopts a categorical approach in which canons "trump" Chevron, displacing the agency's interpretive role altogether. A minority, including the Ninth Circuit, concludes the opposite: that courts should not apply canons, but instead should leave full interpretive discretion to agencies. This Article rejects both categorical approaches and proposes an alternate analytic framework. It argues that whether an agency policy comports with background norms should be considered as part of Chevron's case-by-case, step-two inquiry into whether the policy is reasonable. Unlike the categorical approaches, this context-sensitive solution creates incentives for robust agency norm protection in the first instance, but also permits courts to apply normative canons independently when administrative decisionmaking either offers little advantage, or fails to account for the background values it implicates. This solution also cabins judicial discretion to resolve broader policy questions and compels courts to be clearer about when, and why, different canonic formulations should apply and the implications for agency input. In sum, it best enlists the capacity of the administrative state to promote accountable and informed deliberation on the balance between regulatory goals and norms of constitutional dimension.
\end{abstract}

A U TH OR. Assistant Professor of Law, University of California, Berkeley, School of Law (Boalt Hall). Many thanks to Eric Biber, Lisa Bressman, Tino Cuéllar, Jody Freeman, Philip Frickey, Jacob Gersen, Kristin Hickman, Daniel Ho, Jerry Mashaw, Jonathan Masur, Gillian Metzger, Anne Joseph O'Connell, Catherine Sharkey, Matthew Stephenson, Peter Strauss, Cass Sunstein, Molly van Houweling, Kathryn Watts, Phil Weiser, and other participants in the Summer 2007 Junior Administrative Law Scholars Conference, the ABA Administrative Law Section's 2006 Fall Conference, and the Boalt Hall Junior Working Ideas Group for generous and helpful comments, and to Brent K. Nakamura and Christina Stevens for superb research assistance. 


\section{ARTICLE CONTENTS}

INTRODUCTION

I. THE PROBLEM: COMPETING METHODS FOR RESOLVING STATUTORY AMBIGUITY

A. The Judicial Tools of Statutory Interpretation $\quad 70$

B. Statutory Interpretation After Chevron $\quad 74$

$\begin{array}{ll}\text { C. The Tension Between Canons and Chevron } & 75\end{array}$

II. THE EXISTING APPROACH: CATEGORICAL RESPONSES TO THE CHEVRONCANONS CONFLICT

A. The Majority Rule: Canons Trump Deference $\quad 77$

1. The Majority Rule in the Courts $\quad 77$

2. Justifications for the Majority Rule $\quad 78$

B. The Minority Rule: Deference Trumps the Canons 81

1. The Minority Rule in the Courts $\quad 81$

2. Justifications for the Minority Rule $\quad 82$

III. RECONCEIVING NORMATIVE CANONS IN THE REGULATORY CONTEXT 84

A. Canonic Goals and Institutional Solutions $\quad 85$

B. Changing the Institutional Context: Canons in the Administrative State 89

1. Doctrinal Discretion and Agency Capacity 91

2. Operative Discretion and Judicial Limits 103

3. Replacing Context for Category 107

IV. FINDINC A HOME FOR CONTEXTUAL APPLICATION OF NORMATIVE

CANONS: RECONCILING GOALS UNDER CHEVRON'S STEP-TWO INQUIRY 108

$\begin{array}{ll}\text { A. Incomplete Beginnings } & 108\end{array}$

B. A Home for Canons at Chevron's Step Two 111

1. Placing Canons in Step Two: Suggestions from the Outlier Cases 112

2. Exploring a Step-Two Canons Analysis $\quad 114$

3. Possible Critiques: Considering Costs 121 


\section{INTRODUCTION}

Statutes do not operate in a vacuum. Choices about their meaning do not affect only the substantive areas of law they govern. They also implicate a variety of background norms - like respect for the rights of regulated parties, protection of the interests of states and Native American tribes, avoidance of government bias, and separation of powers-inspired, not by Congress's command, but by the substantive and structural concerns of the Constitution. How, then, should we ensure that statutes are interpreted to reflect these important background norms? To which institution should we assign the task?

Courts have traditionally taken on the responsibility, but with some expression of ambivalence. Lacking policy expertise, fact-finding capacity, and the competence to make political choices, courts recognize that they are often institutionally ill suited to balance policy goals against extrastatutory norms. They have thus developed "normative" canons of construction, like those against reading statutes to raise constitutional issues, or to preempt state tort protections, or to affect tribal power detrimentally. These default rules are intended to predetermine interpretive outcomes protective of values that judges, cautious about their capability to weigh competing interests accurately and make political decisions, might otherwise underenforce.

Judicial application of normative canons, however, fits uncomfortably with the fundamental premise of Chevron U.S.A. Inc. v. Natural Resources Defense Council, Inc., ${ }^{1}$ the formative case governing the allocation of interpretive authority in the administrative state. Under the preexisting canons regime, courts resolve statutory ambiguity conclusively, by resort to judge-made canonic presumptions. Yet after Chevron, when a statute is unclear, the resulting discretion belongs generally to the agency charged with its administration. That agency-armed with the very expertise and political sensitivity courts lack-may (so long as it meets a requisite level of decisionmaking formality) adopt any policy permitted by the scope of statutory indeterminacy.

This tension has split courts and commentators. A majority, including the Supreme Court, argues that courts should continue to interpret legislation independently when normative canons would apply, even when Congress has charged a particular agency with the statute's administration. Canons, they conclude, involve the type of legal question best resolved by independent courts, rather than political agencies. More specifically, canons operate simply as clear-statement rules that constrain interpretive discretion and simply turn

1. 467 U.S. 837 (1984). 
politically sensitive questions back to Congress. Accordingly, they leave no space for agency input, and judges should continue to fix statutory meaning independently when canonic values are implicated.

A minority, including the Ninth Circuit, takes the opposite stance. Relying on Chevron's generalized understandings about superior agency expertise and political accountability, this account decries any continued judicial role in policing normative canons. It leaves to agencies the task of balancing both those goals reflected in statutory language and those left out.

This Article rejects both all-or-nothing approaches. After describing, in Parts I and II, the Chevron-canons conflict and the response of courts and commentators, it argues, in Part III, that the categorical approaches rest on stylized and unrealistic claims about both canons and institutional decisionmaking, with detrimental results.

Normative canons do not, as a practical matter, uniformly constrain interpretive discretion or uniformly return sensitive questions to Congress. Indeed, they do not uniformly do anything. Rather, both collectively and individually, they vary greatly in their formulation and their application. In some contexts, normative canons operate as strong clear-statement rules, asking simply whether legislative text explicitly permits a particular outcome. Yet in others, they permit significant leeway to balance competing policies in light of the practical implications of various interpretive choices.

Just as canon application varies greatly by context, so does agency capacity to contribute to the analysis. As a general matter, agencies are more likely than courts to possess the resources needed to engage in interest balancing and to assess the practical impact of normative policy choices that some doctrinal formulations for canon application require. Moreover, the permeability of agency decisionmaking both permits political inputs by Congress and offers a forum for representation, deliberation, and dialogue that involves a range of stakeholders and experts from inside and outside the agency. In addition to the decision-making transparency fostered by procedures under the Administrative Procedure Act (APA), agencies might, and in some circumstances have, developed a host of processes such as public hearings, consultations with states and Native American tribes, independent oversight boards, and procedures for notifying and gaining input from Congress, geared to ensure that secondary mandates - norms external to the principal goal of the statute they are charged with implementing-are effectively reflected in public policy. Yet the fact of agency competence generally means neither that the normative context will raise issues regarding which an agency can make an institutional contribution, nor that, if it does, the agency will.

The categorical approaches to resolving the Chevron-canons conflict ignore both the variability in canon application and the contingency of agency 
capacity. Specifically, a rule excluding agencies entirely from resolving statutory ambiguity when canonic norms are implicated fails to justify an allor-nothing preference for judicial, rather than agency, discretion in three important ways. First, such a rule ignores the fact that agencies, in some circumstances, may possess greater capacity than courts for norm balancing. Second, it fails to provide any incentive for agencies to account for those values in their own decisionmaking. Such incentive would further the canons' strong policy of judicial restraint by obviating the need for judicial canon application in an important set of cases, as well as promote canons' goal of norm protection in the range of agency actions that never reach a courtroom. Third, it disregards important limits on judicial authority. Judges applying normative canons independently to strike down agency interpretations face no constraint on their discretion to reach an authoritative construction of the statute, even when other permissible solutions exist. Such expansive decisionmaking reflects the very type of judicial aggrandizement the Supreme Court rejected three years ago in National Cable $\mathcal{E}$ Telecommunications Ass'n $v$. Brand $X$ Internet Services (Brand $X){ }^{2}$ yet contributes nothing to norm protection.

At the same time, a rule eliminating the judicial role in policing the application of normative canons after Chevron fails to recognize the unreliability of the agency contribution, especially in protecting values which are systemically underenforced. Such a rule removes incentives for agencies to account for such norms and constitutes, as a practical matter, a determination that certain important public values need not be consistently reflected in public policy.

Part III therefore concludes that the goals of both normative canons and Chevron require a contextual analysis - an institutionally sensitive framework that takes into account the particularity of governing doctrine and actual agency behavior in each case.

Part IV argues that such a framework exists in the reasonableness inquiry of Chevron's second step. Specifically, it contends that courts should consider every agency action otherwise deserving of Chevron analysis, whether it implicates the values underlying normative canons, within Chevron's two-step framework. If the statute proves ambiguous under the standard judicial stepone analysis, courts should consider the background values animating the canons in its determination of the agency interpretation's reasonableness - an inquiry already structured to vindicate a host of extrastatutory norms. Pursuant to this analysis, courts should determine whether an agency policy sufficiently reflects the background norm - if in a particular case the agency's expertise,

2. 545 U.S. 967 (2005). 
decision process, and substantive outcome point to a satisfactory resolution of norm balancing-or whether courts should intercede and apply the default rule. If courts find that an agency has overstepped its bounds, the judicial inquiry should cease. Unlike independent judicial canon application, courts could no longer proceed to a resolution of the statute's meaning, but would essentially "remand" the issue to the agency to exercise (or not) whatever statutory discretion remained.

Step two offers a single operative framework that can both accommodate and sharpen the contested jurisprudence regarding the protection of background norms. It can adapt to the variety of normative canons employed by courts, the variability in their application, and doctrinal changes over time. Moreover, by admitting a role for agencies, a step-two solution can require that judges be clearer in explaining the characteristically muddled canons jurisprudence. Courts will have to be explicit about which aspects of an interpretive decision trigger which particular canonic formulation, which types of agency behavior might contribute to the analysis, and what the governing standard suggests about both the limit of judicial interpretive authority and the remaining space for administrative policymaking. The resulting case law might not only aid in the more consistent use of canons in the judicial review of agency policy, but also help rationalize canon doctrine, and thus promote uniformity in the protection of important values more broadly.

Incorporating a context-sensitive, case-by-case application of normative canons into Chevron's second-step reasonableness analysis offers the best framework for enlisting the comparative strengths of both courts and agencies. It provides incentives for robust norm protection by agencies in the first instance. It invests courts reviewing norm-impinging agency choices with the power to apply normative canons independently when administrative decisionmaking offers little advantage for norm balancing, and also the ability to vindicate regulatory decisions if agencies exercise their capacity in ways that ameliorate institutional barriers to accurate norm application. It promotes judicial candor and explanation. And it leaves residual discretion to construe regulatory ambiguity with regulators. All told, the step-two framework furthers the goals of both normative canons and Chevron-a preference for political decisionmaking and judicial modesty, flexibility in regulatory implementation, and the reflection of constitutionally inspired values in policymaking-by providing tools for enlisting the capacity of the administrative state to promote accountable deliberation on the balance between regulatory goals and norms of constitutional dimension. 


\section{THE PROBLEM: COMPETING METHODS FOR RESOLVING STATUTORY AMBIGUITY}

\section{A. The Judicial Tools of Statutory Interpretation}

For most of our nation's history, Marbury $v$. Madison's principle that “[i]t is emphatically the province and duty of the judicial department to say what the law is" assigned courts the primary task of interpreting legislation enacted by Congress. ${ }^{3}$ That task is, at the same time, both a positive and normative exercise. On the one hand, courts construing statutes serve - in the traditional formulation-as "faithful agents" to legislative instructions. ${ }^{4}$ They "discern" judgments made by Congress and "carry out decisions they do not make." Yet on the other hand, the formalist notion of a court that simply identifies legislative choices leaves questions of the "best" understanding of Congress's instructions underdetermined. Such imprecision reflects the high level of generality at which statutes articulate goals and purposes, the inherent incompleteness of statutory text, the challenge of ascribing a uniform purpose to legislation involving complex issues and enacted by two independent bodies comprised of hundreds of legislators, ${ }^{7}$ each free to vote for any reason or no reason at all. ${ }^{8}$ Even strong defenders of interpretive fidelity to legislative instructions, then, recognize that beneath a description of statutory

3. 5 U.S. (1 Cranch) 137,177 (1803).

4. See, e.g., John F. Manning, The Absurdity Doctrine, 116 HARV. L. Rev. 2387, 2393-94 (2003) ("In our constitutional system, it is widely assumed that federal judges must act as Congress's faithful agents.").

5. Cass R. Sunstein, Interpreting Statutes in the Regulatory State, 103 HARV. L. REV. 405, 415 (1989) (discussing the "most prominent conception of the role of the courts in statutory construction," in which the judicial task is to "discern and apply a judgment made by others, most notably the legislature").

6. Frank H. Easterbrook, The Supreme Court, 1983 Term-Foreword: The Court and the Economic System, 98 HARV. L. ReV. 4, 60 (1984); see also John F. Duffy, Administrative Common Law in Judicial Review, 77 TEX. L. REV. 113, 116 (1998) ("[U]nder classical schools of interpretation, courts deciding statutory cases are bound to follow commands and policies embodied in the enacted text -commands and policies that the courts did not create and cannot change.").

7. See, e.g., Kenneth A. Shepsle, Congress Is a "They," Not an "It": Legislative Intent as Oxymoron, 12 INT'L REV. L. \& ECON. 239 (1992) (discussing the problem of ascribing congressional intent).

8. See generally Kenneth A. Bamberger, Note, Deference to Legislative Fact Determinations in First Amendment Cases After Turner Broadcasting, 111 HARV. L. REV. 2312, 2321-22 (1998) (“[T]o enact legislation legitimately, Congress need not prepare any factual record, articulate any reasons for its decisions, or even have any such reasons.") (citations omitted); id. (citing cases). 
construction as the vindication of legislative choices lies the reality that statutory ambiguity will always leave discretion in the hands of those assigned the interpretive task. ${ }^{9}$

Courts, therefore, have derived a set of tools to guide their independent judgment on the question of statutory ambiguity, in aid of determining conclusively what Justice Story called the "true construction of the laws," which then "bind future cases of the same nature" Congress revisits the issue on its own.

For the most part, these approaches fix statutory meaning by reference to the legislation itself. Judges interpreting a statute begin with an examination of the statute's language, structure, and purpose, as well as a variety of textual or syntactic canons of construction-for example, the rule against reading a text so as to create surplus language, ${ }^{11}$ the canon that different statutory sections are to be interpreted consistently with one another, ${ }^{12}$ and the canon that each statutory provision should be given effect ${ }^{13}-e a c h$ justified as a means for ensuring that interpretation reflects the linguistic conventions of the legislative authors. $^{14}$

9. See, e.g., John F. Manning, Deriving Rules of Statutory Interpretation from the Constitution, 101 Colum. L. REv. 1648, 1655 (2001) (acknowledging judicial discretion in the face of statutory ambiguity); Jonathan T. Molot, Reexamining Marbury in the Administrative State: A Structural and Institutional Defense of Judicial Power over Statutory Interpretation, 96 Nw. U. L. REV. 1239, 1253 (2002) (" $[E]$ ven the Founders understood that judicial interpretation often would require independent judgment rather than rote obedience to legislative instructions."); see also William N. Eskridge, Jr. \& Philip P. Frickey, Statutory Interpretation as Practical Reasoning, 42 STAN. L. REV. 321, 325 (1990) (describing the failure of "objective" interpretive standards to "constrain the discretion of judicial interpreters"); Daniel A. Farber, Statutory Interpretation and Legislative Supremacy, 78 GEO. L.J. 281, 284 (1989) (" $[\mathrm{A}]$ gents do not simply execute orders that their principals give. Rather, agents act on their principals' behalf, carrying out orders that may be subject to multiple interpretations in light of their understanding of the principals' overarching goals.").

10. 1 JOSEPH Story, COMmentaries on the CONSTitution OF the UNITEd States 349 (Boston, Hilliard, Gray \& Co. 1833).

11. See, e.g., Nat'l Credit Union Admin. v. First Nat'l Bank \& Trust Co., 522 U.S. 479, 501 (1998).

12. See, e.g., United Transp. Union-Ill. Legislative Bd. v. Surface Transp. Bd., 169 F.3d 474, 480 (7th Cir. 1999).

13. See, e.g., Halverson v. Slater, 206 F.3d 1205, 1207 (D.C. Cir. 2000).

14. See Elizabeth Garrett, Step One of Chevron v. Natural Resources Defense Council, in A Guide to Judicial and Political Review of Federal Agencies 55, 69 (John F. Duffy \& Michael Herz eds., 2005) ("Many textual (or syntactic) canons are guides to what a particular statutory provision would typically mean to an ordinary speaker of the language. They reflect shared linguistic conventions and understandings, and thus they are helpfully, and uncontroversially, used by courts at step one."). 
Yet courts have also developed a second set of interpretive tools reflecting general norms exogenous to the legislative enactment itself. ${ }^{15}$ Central among these "normative canons"16 are rules of construction that reflect important, often constitutionally inspired principles ${ }^{17}$ that there is reason to think Congress, for a variety of reasons, will not safeguard adequately, and that are traditionally underenforced by courts. ${ }^{18}$ If textual canons offer tools for deciphering evidence of statutory meaning supplied by Congress itself, normative canons draw on a range of values derived elsewhere to resolve legislative ambiguity.

Take, as examples, three canons applied by contemporary courts to regulatory statutes, each grounded in a very different normative foundation ${ }^{19}$ : (1) the rule that a court should construe ambiguous statutes to avoid raising serious constitutional problems (the "avoidance canon"); ${ }^{20}$ (2) the

15. Cass R. Sunstein, Law and Administration After Chevron, 9o CoLUM. L. REV. 2071, 2111 (1990) ("By using these principles, courts decide cases of statutory meaning by reference to something external to legislative desires ....").

16. Scholars have assigned different names to categories of canons. See, e.g., William N. Eskridge, Jr. \& Philip P. Frickey, The Supreme Court, 1993 Term-Foreword: Law as Equilibrium, 108 HARV. L. REV. 26 (1994) (referring to textual and substantive canons); Caleb Nelson, Statutory Interpretation and Decision Theory, 74 U. CHI. L. ReV. 329, 355-56 (2007) (reviewing ADRIAN VERMUELE, AN INSTITUTIONAL THEORY OF LEGAL INTERPRETATION (2006)) (adopting the distinction between "descriptive" tools, which are used "for determining the intended meaning," and "normative canons," which are rules that reflect values such as those "the court imputes to our Constitution or to other aspects of our legal traditions," from Stephen F. Ross, Where Have You Gone, Karl Llewellyn? Should Congress Turn Its Lonely Eyes to You?, 45 VAND. L. REV. 561, 563 (1992)).

17. See William N. Eskridge, Jr. \& Philip P. Frickey, Quasi-Constitutional Law: Clear Statement Rules as Constitutional Lawmaking, 45 VAND. L. REV. 593, 598 (1992) ("A good many of the substantive canons of statutory construction are directly inspired by the Constitution ....").

18. See Eskridge \& Frickey, supra note 17, at 630-31; Sunstein, supra note 15, at 2113.

19. This Article does not seek to develop an exhaustive list of normative canons or to engage in the debates as to which canons should be abandoned and which strengthened. Compare Caleb Nelson, Premption, 86 VA. L. ReV. 225 (2000) (arguing for abandoning the presumption against preemption), and Frederick Schauer, Ashwander Revisited, 1995 SUP. CT. REv. 71 (advocating the abandonment of the avoidance canon), with Philip P. Frickey, Marshalling Past and Present: Colonialism, Constitutionalism, and Interpretation in Federal Indian Law, 107 HARV. L. REV. 381, 412-28 (1993) (arguing that, as a historical and conceptual matter, the Native American construction canon is best understood as a strong clear-statement rule). Indeed, Part IV attempts to offer an adaptive analytic framework that is largely agnostic to such debates. Accordingly, recognizing that each canon reflects different underlying values and varies in operation, this Article considers as illustrations a small set of canons applied by courts both inside and outside the Chevron context.

20. See Edward J. DeBartolo Corp. v. Fla. Gulf Coast Bldg. \& Constr. Trades Council, 485 U.S. 568,575 (1988) (" $[\mathrm{W}]$ here an otherwise acceptable construction of a statute would raise 
presumptions against preemption of state law and against reading statutes to alter the traditional state-federal balance (the "federalism canons"); and (3) the canon requiring that statutes be construed liberally in favor of Native Americans (the "liberal construction canon").

Each constrains, by means of default rules of statutory construction, the ease with which legislation may be interpreted to push the limits of federal power. While the avoidance canon most explicitly operates to fortify "important constitutional values against accidental or undeliberated infringement," ${ }^{21}$ the federalism canons reflect structural values of constitutional dimension involving protection from the aggrandizement of federal power against the sovereign states. ${ }^{22}$ Likewise while the liberal construction canon has been characterized as a "sovereignty-inspired canon," ${ }^{23}$ it also reflects norms intended to guard against government bias ${ }^{24}$ as well as sui generis national responsibilities arising out of the historic relationship with the Native American tribes. ${ }^{25}$

As a whole, then, these diverse normative canons reflect "values that the court imputes to our Constitution or to other aspects of our legal traditions." ${ }^{26}$ They constitute means for resolving ambiguity when legislative instructions are incomplete. And although these rules, as a practical matter, reflect a countermajoritarian pedigree, in that they constitute judicially constructed defaults that may outweigh contrary suggestions drawn from the statutes themselves, they also are often framed in terms of fictions about legislative

serious constitutional problems, the Court will construe the statute to avoid such problems unless such construction is plainly contrary to the intent of Congress.").

21. Eskridge \& Frickey, supra note 17 , at 631 .

22. See Watters v. Wachovia Bank, N.A., 127 S. Ct. 1559, 1585 (2007) (Stevens, J., dissenting) (" $[\mathrm{T}]$ he reasons for adopting [the Tenth] Amendment are precisely those that undergird the well-established presumption against preemption.").

23. Cass R. Sunstein, Nondelegation Canons, 67 U. CHI. L. REV. 316, 332-33 (2000) (categorizing the Indian liberal construction canon as a "sovereignty-inspired" canon).

24. See Sunstein, supra note 15 , at 2115-16 (discussing principles reflecting "self-conscious efforts to counteract administrative or governmental bias").

25. See Peter S. Heinecke, Comment, Chevron and the Canon Favoring Indians, 60 U. CHI. L. REV. 1015, 1015 (1993) (describing the liberal construction canon as "rooted in the notion of a wardship relation between the U.S. government and the Native American tribes which courts are bound to protect and foster" (citing Worcester v. Georgia, 31 U.S. (6 Pet.) 515 (1832))).

26. Nelson, supra note 16 , at 356 . See generally David L. Shapiro, Continuity and Change in Statutory Interpretation, 67 N.Y.U. L. REV. 921, 925 (1992) (describing canons as aids "in reading statutes against the entire background of existing customs, practices, rights, and obligations," which "emphasize the importance of not changing existing understandings any more than is needed to implement the statutory objective"). 
intent $^{27}$ - for example, reflecting an assumption that "Congress intends its statutes to benefit the tribes" 28 or a principle that courts should "not lightly assume that Congress intended to infringe constitutionally protected liberties or usurp power constitutionally forbidden it."29

\section{B. Statutory Interpretation After Chevron}

The Supreme Court's Chevron decision overhauled many of the traditional premises of statutory interpretation. Ending a regime in which judges possessed great leeway in exercising their independent judgment as to the meaning of statutes, ${ }^{30}$ Chevron announced a rule that agencies, rather than courts, possess primary authority for resolving ambiguities or gaps in a regulatory statute. Their reasonable interpretations of ambiguous statutes, accordingly, deserve judicial deference.

Consistent with this premise, Chevron's two-step framework allocates various interpretive tasks between judges and administrative agencies. Chevron's first inquiry tracks the positive component of statutory construction, which it continues to assign to courts. At step one of the analysis, then, judges should use "traditional tools of statutory construction" to ascertain "whether Congress has directly spoken" on an issue. ${ }^{31}$

Yet where legislative instructions are unclear or silent, the Court attributes to Congress a fictive desire as to who is meant to resolve questions that arise in regulatory implementation. "We accord deference to agencies under Chevron," the Court has explained, "because of a presumption that Congress, when it left ambiguity in a statute meant for implementation by an agency, understood that the ambiguity would be resolved, first and foremost, by the agency." ${ }^{2}$

27. See generally Eben Moglen \& Richard J. Pierce, Jr., Sunstein's New Canons: Choosing the Fictions of Statutory Interpretation, 57 U. CHI. L. REV. 1203, 1206-18 (1990) (discussing fictions in statutory interpretation); $i d$. at 1211 ("The methods available for divining collective intent require... resort to the patently untrue.").

28. Chickasaw Nation v. United States, 534 U.S. 84, 95 (2001).

29. Edward J. DeBartolo Corp. v. Fla. Gulf Coast Bldg. \& Constr. Trades Council, 485 U.S. 568 , 575 (1988).

30. See Pittston Stevedoring Corp. v. Dellaventura, 544 F.2d 35, 49 (2d Cir. 1976) (describing, eight years before Chevron, the "impressive body of law sanctioning free substitution of judicial for administrative judgment when the question involve[d] the meaning of a statutory term"); Kenneth A. Bamberger, Provisional Precedent: Protecting Flexibility in Administrative Policymaking, 77 N.Y.U. L. REV. 1272, 1280-81 (2002).

31. Chevron U.S.A. Inc. v. Natural Res. Def. Council, Inc., 467 U.S. 837, 842, 843 n.9 (1984).

32. Smiley v. Citibank (S.D.), N.A., 517 U.S. 735, 740-41 (1996). 
Accordingly, where agencies make normative choices left by ambiguous statutes - at least when they do so in a form that Congress intended to have the "force of law" 33 -judicial inquiry at Chevron's second step is limited to whether the agency action was "reasonable." 34

The notion that statutory ambiguity should be understood to indicate an implicit legislative delegation of interpretive authority to administrative agencies established a constitutional justification for the reality of broad administrative policymaking. That justification, in turn, rested on arguments about institutional competence and structure: the comparative strength of administrative policymaking expertise and agencies' greater sensitivity to political accountability and claim to democratic legitimacy. ${ }^{35}$

Both the normative canons and Chevron, then, are rooted in fictions about Congress's wishes. On the one hand, Congress would want ambiguity in its enactments to be resolved by presumptions reflecting important background norms. On the other hand, it would wish ambiguity to be resolved administratively by agencies. Each of these fictions, moreover, rests on largely empirical institutional claims: that courts interpreting statutes are well situated to protect certain values Congress may neglect, and that administrative decisionmaking offers superior capacity to "resolv[e] the competing interests which Congress itself either inadvertently did not resolve, or intentionally left to be resolved . . . in light of everyday realities." ${ }^{36}$

\section{The Tension Between Canons and Chevron}

Chevron's presumption regarding the appropriate institutional locale for policy implementation in the face of statutory silence creates significant ambiguity of its own. Specifically, it leaves unclear which of the interpretive tools traditionally used by judges to guide their independent judgment about

33. United States v. Mead Corp., 533 U.S. 218, 221 (2001). By contrast, interpretations reflected in other forms of agency action are generally reviewed under the standard of Skidmore $v$. Swift $\mathcal{E}^{\prime}$ Co., 323 U.S. 134 (1944), and upheld only if they are "persuasive[]." Mead, 533 U.S. at 221.

34. See Chevron, 467 U.S. at 845 .

35. See id. at 865 ("Judges are not experts in the field, and are not part of either political branch of the Government.... In contrast, an agency to which Congress has delegated policymaking responsibilities may, within the limits of that delegation, properly rely upon the incumbent administration's views of wise policy to inform its judgments. While agencies are not directly accountable to the people, the Chief Executive is, and it is entirely appropriate for this political branch of the Government to make such policy choices .....").

36. Id. at $865-66$. 
the best construction of a statute survives Chevron's circumscription of the judicial interpretive role.

To be sure, Chevron states that courts should utilize the "traditional tools" for the construction of statutes when discerning, at step one, whether Congress actually spoke to the issue at hand. ${ }^{37}$ Inquiries into the statute's text, structure, and purpose, as well as traditional textual construction canons, fit well within that step's positive inquiry, and their continued application to regulatory statutes is uncontroversial. ${ }^{38}$

Yet this directive is inconclusive as to which fiction about legislative intent-the canons' or Chevron's-should govern when the statute is ambiguous and its resolution would implicate extrastatutory norms unrelated to Congress's actual instructions. When the question under consideration involves resolving the appropriate balance of competing norms - the protection of wetlands as against intrusions on state and local planning power; election law disclosures as against privacy rights; effective hydroelectric energy management as against Indian treaty fishing rights; in short: the goals embodied in legislation as against background constitutional or legal normsshould statutory ambiguity be resolved by courts applying normative canons, as it was previous to Chevron? Or are these the kind of normative questions that should, after that decision, be assigned to agency judgment?

\section{THE EXISTING APPROACH: CATEGORICAL RESPONSES TO THE CHEVRON-CANONS CONFLICT}

Courts have struggled in resolving this question. Consistent with Chevron's statement that courts should employ traditional tools at step one of their analysis, and recognizing that using ambiguity-resolving normative canons at that point would preclude advancement to the second step's deferential inquiry, the question is most often framed in categorical terms: whether a particular canon or presumption survives the Chevron regime. If a court determines that a canon survives, then it "trumps" deferential treatment of agency interpretations altogether and permits the independent judicial resolution of statutory meaning; if not, its application is defeated wholesale by Chevron's rule of deference.

37. Id. at 843 n.9.

38. There is, of course, some dispute regarding the operation of these tools. See generally Antonin Scalia, Judicial Deference to Administrative Interpretations of Law, 1989 DUKE L.J. 511, 521 ("One who finds more often (as I do) that the meaning of a statute is apparent from its text and from its relationship with other laws, thereby finds less often that the triggering requirement for Chevron deference exists."). 


\section{A. The Majority Rule: Canons Trump Deference}

\section{The Majority Rule in the Courts}

The largest group of cases to consider the place of normative canons in review of agency interpretations treats them as the type of "traditional tools" that courts may use to resolve textual ambiguity, even when faced with an agency construction that might otherwise be entitled to deferential Chevron review.

In Edward J. DeBartolo Corp. v. Florida Gulf Coast Building \& Construction Trades Council ${ }^{39}$ and several other cases ${ }^{40}$ the Supreme Court has held that the avoidance canon requires that courts "independently inquire whether there is another interpretation" ${ }^{41}$ when an administrative policy choice raises serious constitutional concerns, even though that choice is otherwise "thought to be a permissible one." ${ }^{22}$ The cases frame the issue in the touchstone language of congressional intent. The independent judgment requirement, Justice White wrote in DeBartolo,

not only reflects the prudential concern that constitutional issues not be needlessly confronted, but also recognizes that Congress, like this Court, is bound by and swears an oath to uphold the Constitution. The courts will therefore not lightly assume that Congress intended to infringe constitutionally protected liberties or usurp power constitutionally forbidden it. ${ }^{43}$

In other contexts, the Court has declined to apply Chevron to agency determinations regarding preemption, ${ }^{44}$ as well as those implicating other

39. 485 U.S. 568 (1988).

40. See, e.g., Solid Waste Agency v. U.S. Army Corps of Eng'rs, 531 U.S. 159 (2001) (following DeBartolo and applying constitutional avoidance and federalism canons to trump Chevron).

41. DeBartolo, 485 U.S. at 577.

42. Id.

43. Id. at 575 .

44. See, e.g., Geier v. Am. Honda Motor Co., 529 U.S. 861, 883, 886 (2000) (stating that the Court would give "some weight" to the agency view while resolving the question independently). The actual standard appropriate for reviewing preemption decisions was raised in Watters $\nu$. Wachovia Bank, N.A., 127 S. Ct. 1559 (2007), but ultimately left undecided. See generally Catherine M. Sharkey, Products Liability Preemption: An Institutional Approach, 76 GEO. WASH. L. REV. 449, 472 (2008) (characterizing the Supreme Court's 
canons such as the presumptions against statutory retroactivity ${ }^{45}$ and the extraterritorial application of law. ${ }^{46}$ And although the Supreme Court has not squarely addressed the relationship between Chevron and the Indian liberal construction canon, a number of courts of appeals have followed the Supreme Court's general canon case law, holding that the Indian canons, ${ }^{47}$ as well as the presumption against preemption, ${ }^{48}$ the avoidance canon, ${ }^{49}$ and other construction rules, ${ }^{50}$ each trump Chevron's deference regime in this manner.

\section{Justifications for the Majority Rule}

Courts and commentators raise two sorts of institutional justifications for this choice. The first involves claims about the comparative competence of agencies and judges. The presumption against preemption should trump Chevron deference both to remedy structural bias - the fact that "agencies are clearly not designed to represent the interests of States"51 - and because of the

jurisprudence on the appropriate treatment of agency preemption positions as "cryptic at best").

45. See INS v. St. Cyr, 533 U.S. 289, 320 (2001) (finding that Chevron was inapplicable because of the "presumption against retroactive application of ambiguous statutory provisions"-a presumption "buttressed by the longstanding principle of construing any lingering ambiguities in deportation statutes in favor of the [noncitizen]" (internal quotation marks omitted)).

46. See EEOC v. Arabian Am. Oil Co., 499 U.S. 244 (1991).

47. See, e.g., Ramah Navajo Chapter v. Lujan, 112 F.3d 1455, 1462 (10th Cir. 1997) (holding that the canon of liberal construction favoring Native Americans restricts Chevron deference).

48. Colo. Pub. Utils. Comm'n v. Harmon, 951 F.2d 1571, 1579 (10th Cir. 1991) (extending no deference on a question of preemption); see also Smiley v. Citibank (S.D.), N.A., 517 U.S. 735,744 (1996) ("assum[ing] (without deciding) that" the question of whether a statute is preemptive "must always be decided de novo by the courts").

49. See, e.g., Whitaker v. Thompson, 353 F.3d 947, 952 (D.C. Cir. 2004) (suggesting that a successful claim under the avoidance canon would "require [the court] to abandon or qualify Cheuron deference").

50. See generally Ojeda-Terrazas v. Ashcroft, 290 F.3d 292, $300 \& \mathrm{n} .53$ (5th Cir. 2002) (holding that the presumption against retroactive application of immigration statutes trumps Chevron deference); Goncalves v. Reno 144 F.3d 110, 127 (1st Cir. 1998) (noting that "it is a significant question whether the determination of the application of the effective date of a governing statute is the sort of policy matter which Congress intended the agency to decide and thus whether the doctrinal underpinnings of Chevron are present here," but concluding, citing Chevron's "traditional tools of statutory construction," that the "plain statement" presumption against retroactive application trumps Chevron).

51. Geier v. Am. Honda Motor Co., 529 U.S. 861, 908 (2000) (Stevens, J., dissenting). See generally Roderick M. Hills, Jr., Against Preemption: How Federalism Can Improve the National Legislative Process, 82 N.Y.U. L. REV. 1, 15 (2007) ("Bureaucrats ... tend to resist or at least 
nature of the analysis: in the words of one court, preemption determinations involve "matters of law - an area more within the expertise of the courts than within the expertise of the [agency]." 52 The Indian liberal construction canon similarly identifies the appropriate location for interpretation not at the agency, which lacks political incentive to protect Native American interests, ${ }^{53}$ but with the tribe. "[I]f the [statute] can reasonably be construed as the Tribe would have it construed," another court has explained, "it must be construed that way." Similar concerns about both agency competence and institutional incentives justify the displacement of deferential review by the avoidance canon. "When agencies adopt a constitutionally troubling interpretation," a third court has asserted, "we can be confident that they not only lacked the expertise to evaluate the constitutional problems, but probably didn't consider them at all." 55

Institutional separation of powers values have also been marshaled for the argument that "[i]n this area, an exception to the Chevron principle, calling for invalidation of agency decisions at Step One, is entirely appropriate." ${ }^{26}$ In the account proffered by Cass Sunstein, for example, canons reflect a singular requirement that certain important issues be addressed by legislative deliberation alone. More specifically, they operate as clear statement rules that bar the interpretation of a statute to push the bounds of federal power absent an unambiguous declaration of intent by Congress. The constitutional avoidance rule, for example, requires that "Congress must decide to raise [a serious constitutional question] via explicit statement," while the Indian

be indifferent to broad policy considerations or claims of abstract justice that do not fall squarely within their regulatory specialty ....").

52. Colo. Pub. Utils. Comm'n, 951 F.2d at 1579; see also Cobell v. Norton, 240 F.3d 1081, 1101 (D.C. Cir. 2001) ("[D]eparture from the Chevron norm arises from the fact that the rule of liberally construing statutes to the benefit of the Indians arises not from ordinary exegesis, but 'from principles of equitable obligations and normative rules of behavior,' applicable to the trust relationship between the United States and the Native American people." (quoting Albuquerque Indian Rights v. Lujan, 930 F.2d 49, 59 (D.C. Cir. 1991))).

53. See Scott C. Hall, The Indian Law Canons of Construction v. The Chevron Doctrine: Congressional Intent and the Unambiguous Answer to the Ambiguous Problem, 37 CONN. L. REv. 495, 559 (2004); Nell Jessup Newton, Federal Power over Indians: Its Sources, Scope, and Limitations, 132 U. PA. L. REV. 195, 202, 245-47 (1984).

54. Muscogee (Creek) Nation v. Hodel, 851 F.2d 1439, 1445 (D.C. Cir. 1988).

55. Williams v. Babbitt, 115 F.3d 657, 662 (9th Cir. 1997).

56. Cass R. Sunstein, Beyond Marbury: The Executive's Power To Say What the Law Is, 115 YALE L.J. 2580, 2607 (2006). 
construction canon ensures "that any unfavorable outcome will be a product of an explicit judgment of the national legislature." ${ }^{57}$

So understood, canons function as substitutes for the now-moribund nondelegation doctrine ${ }^{58}$ invoked by earlier courts to impose constitutional limits on the delegation of legislative power. ${ }^{59}$ They force a democratically elected Congress to deliberate on, and then raise, a question via explicit statement by operating in a manner that constrains any interpretive discretion on the part of courts and agencies. They "trump[] Chevron for that very reason. Executive interpretation of a vague statute is not enough when the purpose of the canon is to require Congress to make its instructions clear." 60

Einer Elhauge explores the implications of Sunstein's descriptive account even more explicitly. ${ }^{61}$ When "enactable preferences" are unclear, he argues, courts should freely utilize normative canons to resolve statutory indeterminacy, even when the result might conflict with less-than-explicit indications of Congress's desires. This is because such interpretations are "preference-eliciting," in that they are likely to provoke Congress to address the issues directly if the judicially determined results do not accord with political preferences. ${ }^{62}$ Using canons, therefore, might be the best way to determine Congress's actual intention without relying on fictitious presumptions regarding legislative will; it forces Congress's hand. By this account, then, the interests that animate such canons arise from fundamental notions as to the structural legitimacy of the administrative state itself. ${ }^{63}$

57. Id. at 2609 .

58. Sunstein, supra note 23 , at 315 (arguing that the nondelegation doctrine has "merely been renamed and relocated" to a variety of canons).

59. See, e.g., Pan. Ref. Co. v. Ryan, 293 U.S. 388, 415 (1935) (striking down section 9 (c) of the 1933 National Industrial Recovery Act on the ground that it permitted presidential interdiction of petroleum trade without any "criterion to govern the President's course"). But see, e.g., Mistretta v. United States, 488 U.S. 361, 372 (1989) (holding that it is constitutionally sufficient if Congress articulates an "intelligible principle" when it "delegate[s] power under broad general directives").

6o. Sunstein, supra note 23 , at 331 ; see also id. at 335 (arguing that nondelegation canons should be understood as way of ensuring "that judgments are made by the democratically preferable institution").

61. Einer Elhauge, Preference-Eliciting Statutory Default Rules, 102 COLUM. L. REv. 2162 (2002).

62. Id.

63. A variety of scholars have, moreover, marshaled such institutional and structural arguments to argue, in the context of particular canons, for a canon-trumps-Chevron rule. See, e.g., Elliot Greenfield, A Lenity Exception to Chevron Deference, 58 BAYLOR L. REV. 1, 61 (2006) (arguing that the rule of lenity "must trump the rule of deference"); Hall, supra note 53, at 497 (arguing that the "Indian law canons should trump Chevron"); Nina A. Mendelson, 


\section{B. The Minority Rule: Deference Trumps the Canons}

\section{The Minority Rule in the Courts}

Different courts of appeals, however, take the opposite approach. They exclude the very same set of canons from the category of traditional tools courts may use to fix statutory meaning, holding that those canons are inapplicable in the Chevron context.

This move is most pronounced in the Ninth Circuit. That court has determined that Chevron deference trumps the Indian liberal construction canon, ${ }^{64}$ the presumption against preemption, ${ }^{65}$ and even, in a 2007 en banc opinion in Morales-Izquierdo $v$. Gonzales, ${ }^{66}$ the constitutional avoidance canon, despite governing Supreme Court precedent.

The majority in Morales-Izquierdo, which upheld a regulation authorizing immigration officers, rather than immigration judges, to reinstate removal orders of aliens who illegally reentered the United States, essentially rested its conclusion on a restatement of Chevron's presumption of legislative intent. "When Congress has explicitly or implicitly left a gap for an agency to fill, and the agency has filled it," wrote Judge Alex Kozinski, "we have no authority to re-construe the statute, even to avoid potential constitutional problems; we can only decide whether the agency's interpretation reflects a plausible reading of the statutory text.. ${ }^{17}$ The four Morales-Izquierdo dissenters, in turn, relied on the contrary presumption regarding legislative intent embodied by the statutes.

Chevron and Preemption, $102 \mathrm{MICH}$. L. Rev. 737, 742 (2004) (arguing that preemption decisions should be withdrawn from the Cheuron framework and committed to judges' discretion); Heinecke, supra note 25; of. Thomas W. Merrill, Preemption and Institutional Choice, 102 Nw. U. L. REV. 727, 771 (2008) (arguing that "courts should not apply the Chevron standard to agency views about preemption" in the face of statutory ambiguity).

64. See Williams v. Babbitt, 115 F.3d 657, 663 n.5 (9th Cir. 1997) ("We have therefore held that the [canon of liberal construction favoring Native Americans] must give way to agency interpretations that deserve Chevron deference because Chevron is a substantive rule of law.").

65. See Wells Fargo Bank N.A. v. Boutris, 419 F.3d 949 (9th Cir. 2005) (deferring to the agency's preemption determination); see also Wachovia Bank, N.A. v. Burke, 414 F.3d 305 (2d Cir. 2005) (same); Teper v. Miller, 82 F.3d 989, 997-98 (11th Cir. 1996) (noting that the "inherent tension" between Chevron and the presumption against preemption but expressing the belief that City of New York v. FCC, 486 U.S. 57 (1988), directed courts to defer to agencies on preemption questions).

66. 486 F.3d 484 (9th Cir. 2007) (en banc).

67. Id. at 493 . 
Relying on the relevant Supreme Court avoidance canon precedents, they argued that

even if the statute were ambiguous, the Attorney General's interpretation would be precluded by the canon of constitutional avoidance-unquestionably a 'traditional tool of statutory construction' to be used at Chevron step one-pursuant to which we must presume that Congress did not intend to permit any interpretation that, like the Attorney General's, raises serious constitutional questions. ${ }^{68}$

\section{Justifications for the Minority Rule}

Deference to agency constructions even when canonic norms are implicated has also been justified by arguments regarding capacity and structure. Adrian Vermeule-who has joined with Sunstein in making the case that questions as to Chevron's scope are best resolved with reference to "institutional considerations" ${ }^{\text {" }}$ - nonetheless reaches the opposite conclusion when applying such analysis to the balance between deference to agency interpretations on the one hand, and other normative canons on the other. ${ }^{70}$

Vermeule argues that since normative canons are general in their terms and disputed in their application, their utility in guiding the detail of statutory particularity is limited, and their treatment in specific cases varies. The judicial application of construction tools beyond a statute's "surface or apparent meaning," ${ }^{71}$ then, merely increases decision costs, with unpredictable results. This further calls into question the canons' utility as "democracy-forcing rules" able to affect congressional behavior. ${ }^{72}$ Indeed, Vermeule argues, there are good reasons to think that such canons are unlikely to promote the legislative deliberation on which they are premised. Rather, in practice, resolving statutory ambiguity by resort to the "rich brew of judge-made canons and collateral sources" functions principally to "read[] agency deference out of the

68. Id. at 500 (Thomas, J., dissenting) (quoting Chevron U.S.A. Inc. v. Natural Res. Def. Council, Inc., 467 U.S. 837,843 n.9 (1984)).

69. Cass R. Sunstein \& Adrian Vermeule, Interpretation and Institutions, $101 \mathrm{MICH}$. L. REv. 885, 926-27 (2003).

70. See Adruan Vermeule, Judging Under Uncertainty: An Institutional Theory of LEGAL INTERPRETATION 198-211 (2006).

77. Id. at 183 .

72. Id. at 198. See generally id. at 132-37. 
picture by narrowing agencies' gap-filling power to the residual area in which judicial tools run out." ${ }^{\text {"3 }}$

If the interpretive benefits accorded by judicial application of normative canons are uncertain, if not marginal, the advantage reaped from assigning agencies the task of balancing the values underlying the canons with those embodied in relevant statutes is high. Specialized agencies and their staffs possess the institutional capacity to master the legislative and technical complexities likely to shed light on Congress's instructions embodied in the familiar statutes they are charged to administer. ${ }^{74}$ They often possess better information regarding the "policy context surrounding [a] statute's enactment," and greater familiarity with the "resulting legislative deal." 75

In the face of superior agency capacity, "[o]nly a kind of blind confidence in judicial capacities could suggest that judges are systematically superior to agency administrators in determining what legislators intended, or what purposes an enacting majority meant to pursue, or what policy tradeoffs the statute made." ${ }^{76}$ The expertise and political accountability that provided the justifications for the Cheuron rule, then, drive the conclusion that " $t \mathrm{t}] \mathrm{he}$ interpretive complexity shunted out of the judiciary would be managed at a lower cost by agencies." 77 Accordingly, courts should not employ any tools for resolving ambiguity on their own, but should instead defer to agency determinations regarding when, and how, to consider canonic values in policymaking, unless Congress "clearly says otherwise." 7

Structural arguments for the minority approach also rely on the policies underlying Chevron. That decision, write Thomas Merrill and Kristin Hickman in considering its interplay with the avoidance canon, rests on the understanding that discretionary policy choices should be made, "to the extent possible, by Congress itself and by accountable agencies rather than by the courts." The avoidance canon, by contrast, "has the opposite effect of

\footnotetext{
73. Id. at 206-07.

74. Id. at 209,215 .

75. Id. at 209.

76. Id.

77. Id. at 215 .

78. Id. at 201; see also Brian Galle \& Mark Seidenfeld, Admin Law's Federalism: Preemption, Delegation, and Agencies at the Edge of Federal Power, 57 DUKE L.J. 1933 (2008) (arguing that, because of the democratic and deliberative institutional capacity of agencies, they should often be permitted to preempt or regulate without judicial constraints requiring express congressional approval).
}

79. Thomas W. Merrill \& Kristin E. Hickman, Chevron's Domain, 89 GEO. L.J. 833, 915 (2001). 
enlarging the scope of policymaking by courts at the expense of Congress and the agencies," and the canon should be "abandoned" in Chevron cases. ${ }^{80}$

Each categorical approach, accordingly, bases its normative conclusions on general descriptive claims - one about the goals and operation of canons, the other about the capacity of agencies. By the majority account, canons constitute mechanisms for judicial vindication of important values, leaving no room for agency input. Their operation as clear statement rules forecloses statutory ambiguity, constrains interpretive discretion, and reflects a singular understanding about the meaning of congressional silence. By the minority account, the values underlying canons are best left to agency implementation, because, as an institutional matter, agencies possess resources and expertise that may best illuminate the interplay between different policy values in the implementation of regulatory statutes. Each side, thus, ultimately privileges one premise to the exclusion of the other, envisioning a process of normative balancing that leaves, in the first instance, no role for the agency, and in the second, no role for courts.

\section{RECONCEIVING NORMATIVE CANONS IN THE REGULATORY CONTEXT}

This Part reconsiders the general claims on which the two categorical approaches to the Chevron-canons conflict rely. Analyzing both the goals embodied in normative canons and their operation, it concludes that the courtconstructed canons mechanism does not reflect an absolute preference for judicial canon application, but rather a means of vindicating certain norms in a particular institutional context-one in which judges independently set the meaning of statutes more broadly.

Far from simply being an inquiry into the existence of an explicit statement, moreover, normative canon application varies by context. It often involves detailed analyses regarding the practical implications of choices between competing norms and frequently leaves a great deal of discretion to those assigned the task of statutory construction.

The contextual nature of canons' operation becomes important when a third type of institution - the administrative agency - is introduced into the mix. The decision-making strength of agencies gives them important institutional advantages in weighing the values reflected by the canons as against the policies reflected in a statute. For a variety of institutional reasons,

80. Id. 
however, those strengths may not be brought to bear in any particular case, especially in the absence of some form of judicial oversight.

This analysis suggests that any reconciliation of the tension between the canons and Chevron is not to be found in a categorical solution. Rather, it requires a contextual approach that considers the actual responsiveness of agency policymaking to the protection of often-underenforced background norms in any particular case. Only sensitivity to context can best enhance the comparative institutional strengths on which the regulatory state relies.

\section{A. Canonic Goals and Institutional Solutions}

Judicially created normative canons constitute mechanisms for promoting certain substantive ends in light of a particular institutional context. On the one hand, they reflect the foundational proposition that when the federal government exercises power, it must do so in a manner respectful of systemic constraints such as the demands of the Constitution, the structural balance of the federal system, and the trust relationship with Native American tribes. On the other hand, they constitute prophylactic means for overcoming shortcomings in decisionmaking by the branches traditionally involved in making and interpreting law-Congress and the courts.

In this sense, canons resemble much constitutional doctrine. Courts faced with the task of "implementing" the Constitution confront generalized norms that may reasonably lead to a variety of outcomes in any given situation. ${ }^{81}$ Faced with this zone of reasonable disagreement, lacking institutional tools for specifying contextual constitutional meaning with full accuracy, and constrained by superior claims of democratic legitimacy by the political branches to whose actions they must hold a constitutional yardstick, courts must develop doctrinal formulations they can apply. These formulations, then, are not operative principles drawn directly from the Constitution. They are, rather, "constitutional decision rules"

81. Richard H. Fallon, Jr., The Supreme Court, 1996 Term-Foreword: Implementing the Constitution, 111 HARv. L. REv. 54, 56-59 (1997); see also Henry P. Monaghan, The Supreme Court, 1974 Term-Foreword: Constitutional Common Law, 89 HARV. L. Rev. 1 (1975) (distinguishing between "real" constitutional law and constitutional common law).

82. See Mitchell N. Berman, Constitutional Decision Rules, 90 VA. L. Rev. 1, 51 (2004) (introducing the distinction between "constitutional operative propositions (essentially, judge-interpreted constitutional meaning) and constitutional decision rules (rules that direct courts how to decide whether a given operative proposition has been, or will be complied with)"); Kermit Roosevelt III, Constitutional Calcification: How the Law Becomes What the Court Does, 91 VA. L. REV. 1649, 1653-55 (2005) (analyzing the distinction). 
Constitution's meaning precisely." ${ }^{83}$ They constitute, then, a particular judicial form of decisionmaking: a second-best means for courts to deal with constitutional questions that arrive on their doorstep, informed by "institutional, sociological, and psychological dynamics," ${ }^{84}$ a concern with both unconstrained case-by-case normative inquiry and overreaching where judicial analysis claims no superior vantage, ${ }^{85}$ and a desire for judicial administrability across cases. ${ }^{86}$

Normative canons similarly provide decision rules that reflect institutional dynamics, such as deficiencies inherent in the legislative and judicial process. Congress, for a variety of reasons, may ignore important structural and constitutional values when legislating. Most basically, Congress may not foresee the ways in which such values may be implicated by the application of the statute under consideration. ${ }^{87}$ When enacting broad-reaching statutes of general application vesting authority in an agency to develop complicated regulatory regimes to address complex social problems, it may, quite rationally, fail to focus on the breadth of contextual application and the values that may be implicated. Statutes intended to do more than implicate an area of recognized sensitivity-such as the National Labor Relations Act, which governs employers generally-will more likely be incomplete regarding subsidiary issues involving, for example, whether statutory provisions govern specific types of employers, such as Native American tribes (implicating values of

83. Fallon, supra note 81 , at 57 .

84. Id. at 150 .

85. Lawrence Gene Sager, Fair Measure: The Legal Status of Underenforced Constitutional Norms, 91 HARV. L. REV. 1212, 1215-20 (1978) (discussing the ways in which equal protection doctrine reflects a decision that independent judicial case-by-case assessments would invite excessive litigation and generate unpredictable and conflicting results).

86. Richard H. Fallon, Jr., Judicially Manageable Standards and Constitutional Meaning, 119 HARv. L. REV. 1275, 1278 (2006) (discussing ways in which judicially formulated tests provide manageable standards-some of which underenforce, and others of which overenforce, underlying constitutional guarantees).

87. See generally William M. Landes \& Richard A. Posner, The Independent Judiciary in an Interest-Group Perspective, 18 J.L. \& ECON. 875, 879 (1975) (" $[T]$ he limits of human foresight, the ambiguities of language, and the high cost of legislative deliberation combine to assure that most legislation will be enacted in a seriously incomplete form, with many areas of uncertainty left to be resolved by the courts."). 
respect for Indian sovereignty) ${ }^{88}$ or churches (implicating constitutional free exercise protections) ${ }^{89}$

Statutory incompleteness arises, furthermore, not only from deficits in perspicacity, but from institutional incentives. To be sure, legislators might easily recognize, and may therefore address, the treatment of constitutional issues in a focused statute, such as one delegating authority to the Federal Communications Commission to regulate broadcast content. But they may find it less costly to leave sensitive issues unresolved than to reach agreement on difficult choices. Moreover, a Congress engaged in the aggressive exercise of federal authority may serve as a poor champion for the competing interests of states, tribal sovereigns, or affected individuals, or for the structural constraints of the Constitution.

Normative canons also reflect shortcomings in judicial capacity. While the resolution of statutory ambiguity generally, by reference to legislative goals and drafting conventions, is understood to fall within the core judicial capacity, settling unanswered questions regarding the balance of extrastatutory norms and legislative goals, by contrast, stretches courts' interpretive competence. As a practical matter, courts are frequently hindered in the investigation and assessment of facts that might illuminate the depth of intrusion that legislation poses to extrastatutory values. The appropriate balance between competing norms is inherently imprecise, and doctrinal formulations make poor guides to a determinate answer. Conceptually, moreover, the decision whether to push, by means of positive law, the boundaries of constitutional limits or the lines between federal authority and state or Indian sovereignty is a quintessentially political one, uncomfortably resolved from courts' countermajoritarian vantage. These institutional constraints, accordingly, counsel judicial modesty. For these reasons, courts may underenforce certain norms. ${ }^{90}$

88. See San Manuel Indian Bingo \& Casino v. NLRB, 475 F.3d 1306 (D.C. Cir. 2007) (holding that the National Labor Relations Act creates jurisdiction over a tribal-owned casino operated on the tribe's reservation).

89. See NLRB v. Catholic Bishop of Chicago, 440 U.S. 490 (1979) (holding that, in view of the absence of a clear expression of Congress's intent, the National Labor Relations Act did not create jurisdiction over teachers in church-operated schools).

90. Sunstein, supra note 5, at 468 ("Federal courts underenforce many constitutional norms, and for good reasons. Institutional constraints - most notably, limited fact-finding capability and attenuated electoral accountability - make courts reluctant to vindicate constitutional principles with the vigor appropriate to governmental bodies with a better democratic and policymaking pedigree."); see also Hiroshi Motomura, Immigration Law After a Century of Plenary Power: Phantom Constitutional Norms and Statutory Interpretation, 100 YALE L.J. 545, 563 (1990) (noting that underenforcement arises from "[i]nstitutional constraints, especially the judiciary's sensitivity to its limited factfinding capability and attenuated electoral 
As transsubstantive default rules, normative canons are intended to provide a second-best means for overcoming these legislative and judicial decisionmaking deficiencies. ${ }^{91}$ By setting the default toward protecting underlying extrastatutory values, canons seek to increase the general accuracy of norm balancing through statutory interpretation. Yet the canons protect systemic separation-of-powers concerns because-as a formal matter-the canons, rather than unconstrained judicial initiative, do the work in pointing toward a substantive result. ${ }^{92}$ In this sense, normative canons work as tools of judicial restraint. At least in theory, by overdetermining the result of an inquiry into statutory meaning, canons remove a great deal of normative discretion from judicial hands by returning sensitive decisions to Congress, so that they may be made in a deliberative manner within politically accountable constraints.

Indeed, the canons each rest in large part on theories of judicial modesty in the face of another institution with greater competence: Congress. The Native American and preemption canons are conceived as means to direct decisionmaking to the legislative forum, where it may be conducted openly, subject to political constraints. ${ }^{93}$ The principal articulation of the avoidance canon frames it as a prudential theory of restraint-a means of finding alternate judicial means of resolving a particular case or controversy and thus "saving" the statute from constitutional challenge, rather than "telling a

responsibility"). See generally Sager, supra note 85, at 1214 (noting that the "important difference between a true constitutional conception and the judicially formulated construct is that the judicial construct may be truncated for reasons which are based not upon analysis of the constitutional concept but upon various concerns of the Court about its institutional role").

91. See Ernest A. Young, Constitutional Avoidance, Resistance Norms, and the Preservation of Judicial Review, 78 TEX. L. REV. 1549, 1585 (2000) ("[S]uch rules are the best way-and perhaps the only way-of giving voice to constitutional norms that are real, not phantoms, and that are generally left underenforced by more conventional types of doctrines.").

92. Daniel B. Rodriguez, The Presumption of Reviewability: A Study in Canonical Construction and Its Consequences, 45 VAND. L. REV. 743, 744 (1992) ("Statutory interpretation is a more incremental, and less rigid, form of judicial decisionmaking than constitutional interpretation. Hence, canonical construction implements important values with less disruption to the political and legislative processes.").

93. See Philip P. Frickey, A Common Law for Our Age of Colonialism: The Judicial Divestiture of Indian Tribal Authority over Nonmembers, 109 YALE L.J. 1, 12 (1999) (describing how the Native American canon forces opponents of tribal authority to "bear the burden of legislative inertia" by, among other things, requiring Congress to change the outcome "by clear statutory language that should flag the issue for legislators and lobbyists who favor Indian interests and that should ensure a fairer legislative fight"); Hills, supra note 51, at 1654 (discussing the presumption against preemption as a means for forcing questions back to the legislative forum). 
coordinate branch that its actions are absolutely prohibited absent constitutional amendment." 94

\section{B. Changing the Institutional Context: Canons in the Administrative State}

Normative canons, in sum, reflect a doctrinal solution tailored to a particular institutional context: the independent judicial interpretation of legislation. How, then, should we think about the best way to achieve their substantive ends-ensuring that positive law incorporates important extrastatutory values-when that context changes? More specifically, do canons leave any place for administrative agencies in deciding about the reflection of canonic norms in regulation?

If Sunstein's account of canons is correct, ${ }^{95}$ then the case law's majority rule preserving independent judicial application of these ambiguity-resolving tools, even after Chevron, may make sense. More specifically, if as a descriptive matter canons operate as on-off rules inquiring straightforwardly into whether an explicit statement appears in statutory text, then it may be sensible to read into them certain normative conclusions: (1) that Congress specifically must exercise, to the extent possible, all discretion as to the balancing of canonic norms within the scope of reasonable disagreement; (2) that canons always constitute the best way to promote judicial restraint while at the same time overcoming the limits of courts' capacity; (3) that canons, therefore, are the best means for prohibiting, through process limits, the undeliberated infringement on the limits of federal power; and (4) that Chevron's general shift of interpretive authority to administrative agencies does not implicate the operation of the canons, because they, in the end, involve the type of positive inquiry into statutory text that Chevron continues to assign exclusively to courts

94. Rust v. Sullivan, 500 U.S. 173, 224 (1991) (O'Connor, J., dissenting); see also Ashwander v. TVA, 297 U.S. 288, 348 (1936) (Brandeis, J., concurring) (setting forth the avoidance canon as a rule of restraint); Trevor W. Morrison, Constitutional Avoidance in the Executive Branch, 106 Colum. L. Rev. 1189, 1202 (2006) (describing a judicial restraint justification as the predominant account of constitutional avoidance). For more cases articulating this position, see, for example, NLRB v. Catholic Bishop of Chicago, 440 U.S. 490, 501 (1979), which describes the canon of constitutional avoidance as "the Court's prudential policy"; University of Great Falls v. NLRB, 278 F.3d 1335, 1340 (D.C. Cir. 2002), which holds that the constitutional avoidance canon of statutory interpretation trumps Chevron because it is an "even more important principle of judicial restraint"; and Lyng $\nu$. Northwest Indian Cemetery Protective Ass'n, 485 U.S. 439, 445 (1988), which states that "[a] fundamental and longstanding principle of judicial restraint requires that courts avoid reaching constitutional questions in advance of the necessity of deciding them."

95. See supra text accompanying notes $56-60$. 
in Chevron's first step. In other words, if judicially applied canons work in this manner, then they may be the best means, rather than simply a contextually sensitive way, to maximize their underlying substantive goals.

An examination of the way canons actually operate, however, suggests otherwise. As a preliminary matter, courts have indicated that the justifications for normative canons-overcoming institutional decisional deficiencies while more accurately achieving a balance between competing values-might argue for different operation in different institutional contexts. Where a constitutional claim may be obviated by the choice between plausible readings of underlying state law issues, for example, the policy against reaching constitutional issues unless they are "really necessary" counsels in favor of certification of the issue to the highest state court. ${ }^{96}$ That institution should be accorded the opportunity to pass on the issue in the first instance, which might resolve the issue, or narrow its scope, before a federal court revisits the question.

More fundamentally, canons simply do not operate in a uniformly discretion-constraining way. While they sometimes return questions to Congress as a means for avoiding judicial resolution, that institutional solution is only one of the doctrinal means canons employ to achieve the twin goals of withholding from making, "with virtually irrevocable finality," decisions that strain their institutional competence, while at the same time "provid[ing] a just result." ${ }^{97}$ Indeed, far from being consistent rules that determine outcomes based on positive inquiries into the statute, canons vary by context, incorporating a variety of standards that create a great deal of leeway in application-leeway that might, in certain circumstances, best be enjoyed by courts, but in others, might not. Any solution to the Chevron-canons conflict, then, requires a more granular identification of the scope and type of discretion that canon application allows and analysis of why, and when, one institution or another - in this case courts or agencies - might best be involved in its exercise.

96. Elkins v. Moreno, 435 U.S. 647, 661-62 (1978); see Town of Castle Rock v. Gonzales, 545 U.S. 748, 773-74 (2005) (Stevens, J., dissenting) (criticizing the majority for departing from this practice and interpreting Colorado law independently).

97. Motomura, supra note 90 , at 573 . 


\section{Doctrinal Discretion and Agency Capacity}

\section{a. Variety in Canons Doctrine}

In some contexts, normative canons are, indeed, formulated rather decisively as the majority case law describes, as the type of positive inquiry into statutory text that Chevron places "within the expertise of the courts." an agency regulation, in the absence of an explicit statement of legislative intent, to interpret a federal statute to constitute a waiver of state sovereign immunity or to rewrite explicit terms of a treaty with a Native American tribe to the tribe's disadvantage-both situations in which the Court has consistently imposed clear statement requirements ${ }^{99}$ - the agency would not have much to add. In applying such a standard, the institutional competence of the judiciary is at its apogee, and a court could straightforwardly apply the canon to invalidate the regulation.

Yet in many contexts, even clear statement rules are not mechanistic in their application. The question of how explicit a congressional indication in the direction of a particular construction must be is often underdetermined by the general rule; therefore, "the clarity required varies over time and by judge." This decisional discretion permits interpreters to ignore strong indications of actual legislative intent by modulating the level of required clarity. ${ }^{101}$ The phenomenon has, in particular, proven a robust source of criticism of the avoidance canon, ${ }^{102}$ under which courts can adopt strained constructions of a

98. Colo. Pub. Utils. Comm'n v. Harmon, 951 F.2d 1571, 1579 (10th Cir. 1991).

99. E.g., Atascadero State Hosp. v. Scanlon, 473 U.S. 234 (1985); United States v. Dion, 476 U.S. 734, 738-39 (1986) (requiring "clear and plain" evidence of congressional intent to abrogate Indian treaty rights to hunt bald eagles).

100. William N. Eskridge, Jr. \& Kevin S. Schwartz, Chevron and Agency Norm-Entrepreneurship, 115 YALE L.J. 2623, 2631 (2006) (citing Eskridge \& Frickey, supra note 16, at 81-87); see also James J. Brudney \& Corey Ditslear, Canons of Construction and the Elusive Quest for Neutral Reasoning, 58 VAND. L. REV. 1 (2005) (discussing the ways in which Justices deploy canons differently according to their political leanings to strike down interpretations with which they disagree).

101. See William N. Eskridge, Jr., Public Values in Statutory Interpretation, 137 U. PA. L. ReV. 1007, 1066 (1989) (discussing the Supreme Court's application of the constitutional avoidance canon in NLRB $v$. Catholic Bishop of Chicago, 440 U.S. 490 (1979), to impose a narrow construction of the National Labor Relations Act that rewrote the statute's comprehensive language and belied a congressional vote against the construction the Court ultimately adopted).

102. See Schauer, supra note 19 (advocating abandonment of the canon altogether on these grounds). 
statute-constructions that Congress may disagree with, or at a minimum not even have foreseen - so as to "save" the statute from potential constitutional invalidation. ${ }^{103}$ Clear statement rules, then, may permit expansive interpretive authority to diverge from existing indicia of legislative will in service of judicial restraint.

Moreover, the interpretation reached by means of discretion inherent in the canons will most often stand undisturbed. Professor Elhauge's assertion that judicial resolution of these important issues in stark ways will promote democratic deliberation by forcing Congress to show its hand and to correct erroneous judicial approximations of its will, ${ }^{104}$ does not, as an empirical matter, ameliorate the discretion concern. The claim is falsified by the reality that "only occasionally and adventitiously will Congress respond to judicial statutory interpretations at odds with original intent or purpose," ${ }^{105}$ and only then if the issue implicates the interests of highly organized and influential groups. ${ }^{106}$ Accordingly, clear statement canons, while purportedly leaving enforcement of norms to the political process, may simply provide "a backdoor way" for the interpreter to proceed and resolve normative questions - and the underlying meaning of statutes - themselves. ${ }^{107}$

Second, although their different articulations reflect the generalized notion that certain sensitive decisions are best directed toward political actors and away from courts, normative canons in many contexts do not operate as clearstatement rules at all. Rather, they involve a number of analytic frameworks, according more or less discretion in implementation, depending on context. Indeed, they frequently operate as prophylactic, but rebuttable, presumptions intended to shape statutory construction so as to protect underlying values that courts might not enforce directly. ${ }^{108}$ Canons often, as the Supreme Court has

103. Adrian Vermeule, Saving Constructions, 85 GEO. L.J. 1945, 1946 (1997) (discussing avoidance as a "saving[s] construction[]" and its "expansive conception" of judicial authority).

104. See supra text accompanying notes 61-63.

105. William N. Eskridge, Jr., Dynamic Statutory Interpretation, 135 U. PA. L. REv. 1479, 1525 (1987).

106. See id.; see also Note, New Evidence on the Presumption Against Preemption: An Empirical Study of Congressional Responses to Supreme Court Preemption Decisions, 120 HARV. L. REv. 1604, 1612 (2007) (finding, in a study of cases from 1983 to 2003, that "Congress almost never overrides the Supreme Court's preemption decisions").

107. Eskridge \& Frickey, supra note 17 , at 635 .

108. See generally J. Harvie Wilkinson III, Toward a Jurisprudence of Presumptions, 67 N.Y.U. L. ReV. 907, 907 (1992) ("There are few absolute principles in law. Those principles that appear to be absolute are, in reality, presumptions which may be overcome in appropriate circumstances."). 
described, "are not mandatory rules," but are instead "guides that 'need not be conclusive." "109

In any particular case, then, whether a presumption applies, and whether it is rebutted, often involves an assessment - and often a balancing - of a variety of factors arising both from the statutory and regulatory scheme, and from the background norm. Our three illustrative canons are instructive.

The avoidance canon, the Supreme Court has explained, "does not apply mechanically whenever there arises a significant constitutional question the answer to which is not obvious." ${ }^{10}$ Rather, it is triggered only after a finding, on one hand, that the question is "serious," and on the other, that the process of statutory construction does not point too strongly in the direction of the constitutionally sensitive interpretation. ${ }^{111}$ In the first case the courts will apply the avoidance canon; in the second they will proceed to resolve the constitutional question directly. ${ }^{112}$

These triggering inquiries are important in understanding the operation of the avoidance canon in two ways. First, the elusiveness of the criteria for triggering the canon accords, in practice, substantial leeway as to when it will be invoked. Accordingly, questions of application are highly contested, and even courts that adopt the majority position on independent judicial application of normative canons decline to employ them in individual cases under review. Most notable is the Supreme Court's controversial decision in Rust $v$. Sullivan, ${ }^{113}$ which reviewed a challenge to Department of Health and Human Services regulations that prohibited projects receiving federal family planning funds from not only providing abortions (as provided by statute), but also counseling, advising, or promoting the idea that a woman seek an abortion. The Rust Court declined to set aside the provisions pursuant to the avoidance canon, concluding that they did not "raise the sort of 'grave and doubtful constitutional questions' that would lead us to assume Congress did not intend to authorize their issuance."

109. Chickasaw Nation v. United States, 534 U.S. 84, 94-95 (2001) (discussing the "pro-Indian canon" (quoting Circuit City Stores, Inc. v. Adams, 532 U.S. 105, 115 (2001))).

110. Almendarez-Torres v. United States, 523 U.S. 224, 239 (1998).

111. See Reno v. Flores, 507 U.S. 292, 314 n.9 (1993) ("Statutes should be interpreted to avoid serious constitutional doubts, not to eliminate all possible contentions that the statute might be unconstitutional." (citation omitted)).

112. See Morrison, supra note 94 , at 1215 ("[T]he standard description of avoidance does not require a true clear statement in order to force the doubts-raising construction.”).

113. 500 U.S. 173 (1991).

114. Id. at 191 (quoting United States ex rel. Att'y Gen. v. Del. \& Hudson Co., 213 U.S. 366, 408 (1909) (citation omitted)). 
construction after finding the statute - which "does not speak directly to the issues of counseling, referral, and advocacy"-ambiguous. ${ }^{15}$ Justice Blackmun, writing in dissent, rejected the majority's manner of dismissing the constitutional question as a "facile response to [an] intractable problem." "16 "Whether or not one believes that these regulations are valid," he wrote, "it avoids reality to contend that they do not give rise to serious constitutional questions." 17

Second, the canon-triggering inquiries suggest something qualitative about the mode of analysis involved in the canon's application. Inquiries into whether a constitutional question is "serious" requires a preliminary assessment of the fact- or context-specific balancing tests inherent in many of the underlying substantive constitutional doctrines. In this way, " $[t]$ he doctrine of compelling governmental interests, which compares 'presumptive' rights against the benefits sought to be achieved by the challenged legislation," has "simply infiltrated and influenced the heavily constitutionalized form of statutory interpretation" typified by normative canons. ${ }^{118}$

Agencies like the Federal Communications Commission, the Federal Election Commission, and the National Labor Relations Board-by regulating the methods of content provision (if not content itself), modes of communication involved with electioneering, or forms of labor activism - swim regularly in constitutionally charged waters. Yet under the balancing tests that govern speech jurisprudence, determining whether agency actions "seriously" implicate First Amendment protections requires the ability to assess not only the government interest they seek to advance, but also significant factual and predictive detail regarding the extent of the restriction on alleged First Amendment freedoms and the comparative effect of theoretical alternative policy choices. These assessments, moreover, change over time and alter the constitutional calculus accordingly. ${ }^{119}$

The Native American canon of liberal construction, which claims its origins in case law requiring explicit legislative expression, ${ }^{120}$ now also operates at

115. Id. at 184 .

116. Id. at 205 (Blackmun, J., dissenting).

117. Id.

118. Vermeule, supra note 103 , at 1972.

119. See generally Stuart Minor Benjamin, Stepping into the Same River Twice: Rapidly Changing Facts and the Appellate Process, 78 Tex. L. REv. 269 (1999) (discussing the way in which changing facts alter constitutional adjudication); Bamberger, supra note 8, at 2317-20 (discussing the centrality of empirical assessment to First Amendment adjudication).

120. See Frickey, Marshalling Past and Present, supra note 19, at 412-28 (tracing the canon's approach to the Indian law approach taken by Chief Justice Marshall, and suggesting its 
different strengths in different circumstances. While the insistence on clear evidence of congressional intent is most robust in the area of treaty construction, ${ }^{121}$ in other situations courts apply a more contextual analysis. More particularly, as with the avoidance canon, much of the discretion arises from the standards triggering the canon's application. The inquiry some courts have adopted to assess whether application of a general law "inappropriately impairs" Native American tribal sovereignty (and therefore merits application of the Native American liberal construction canon), for example, "is not dependent on mechanical or absolute conceptions of ... tribal sovereignty,", but similarly "call[s] for a particularized inquiry into the nature of the state, federal, and tribal interests at stake." ${ }^{122}$ Such analysis involves not only the conceptual assessment of the interests at stake, but also empirical assessments as to the practical effects that the federal scheme would have on tribal revenue and decision-making authority. A pair of recent D.C. Circuit cases applying the canon illustrates the contingent nature of its application. In its 2007 opinion in San Manuel Indian Bingo \& Casino v. NLRB, the court held that, although the canon trumped Chevron under circuit precedent, the court would not apply that test in reviewing an NLRB decision that the NLRB could regulate a tribal casino under the National Labor Relations Act because the agency determination did not impinge on the tribe's sovereignty "enough." 123 More strikingly, in City of Tacoma $v$. FERC, ${ }^{124}$ decided several months earlier, the court similarly declined to apply the Chevron-defeating canon to a Federal Energy Regulatory Commission licensing decision involving a hydroelectric project that emptied part of the Skokomish River, despite the fact that this reduced the Skokomish Tribe's fishing right, guaranteed by the Treaty of Point No Point, to one "of little value, because the water has disappeared, and with it, the fish." 125

Finally, preemption determinations, as well, feature an amalgam of conceptual and balancing analysis. Preemption need not, in every context, be

understanding as a strong clear-statement rule). But see Montana v. Blackfeet Tribe of Indians, 471 U.S. 759, 770 (1985) (White, J., dissenting) (" $[\mathrm{T}]$ his rule is no more than a canon of construction."); Heinecke, supra note 25, at 1034 (asserting that the canon has never been a rule requiring explicit legislative expression).

121. See, e.g., United States v. Dion, 476 U.S. $734,738-39$ (1986) (requiring "clear and plain" evidence of congressional intention to abrogate Indian treaty rights).

122. San Manuel Indian Bingo \& Casino v. NLRB, 475 F.3d 1306, 1313 (D.C. Cir. 2007) (quoting White Mountain Apache Tribe v. Bracker, 448 U.S. 136, 145 (1980)).

123. Id. at 1315 .

124. 460 F.3d 53 (D.C. Cir. 2006).

125. Id. at 62 . 
explicit in statutory language, but may be implied based on a determination whether, among other things, the continued vitality of a state law presents an obstacle to congressional goals. ${ }^{126}$ This inquiry, in turn, involves "very practical questions of the extent of potential interference" with a federal statutory scheme. ${ }^{127}$

\section{b. The Variability of Agency Competence}

\section{i. Agency Capacity}

These doctrinal formulations, then, involve detailed evaluations of the systemic implications of choices made in administering complex regulatory schemes. Such evaluations, in turn, are particularly well suited to the general agency capacities on which administrative delegation is premised. Indeed, the shortcomings of judicial capacity, which canons are, at least in part, intended to overcome-inferior capacity for fact-finding and policymaking on one hand, and a hesitance to strike down, on direct constitutional grounds, legislation enacted through democratic processes, on the other-are the very same competencies at which agencies may excel.

Most basically, the technical and empirical analysis as to the effects of policy choices plays to the same agency strengths that underlie Chevron's rule of deference. Such assessment, like implementation of statutes generally, requires a granular, contextual analysis that takes into account facts on the ground. It necessitates a "full understanding of the force of the statutory policy in the given situation"; ${ }^{128}$ it accounts for "everyday realities"; ${ }^{129}$ and it requires evolving assessment in light of changing circumstances. ${ }^{130}$ Agencies, then, may possess a unique vantage for understanding the factual details underpinning the constitutional implications of particular policies, or the interaction between

126. See Hines v. Davidowitz, 312 U.S. 52, 67 (1941) (describing field preemption and conflict preemption as forms of implied preemption).

127. Mendelson, supra note 63, at 788; see also Fla. Lime \& Avocado Growers, Inc. v. Paul, 373 U.S. 132, 142 (1963) (holding that preemption can occur either because "Congress has unmistakably so ordained," or because of "persuasive reasons" arising from "the nature of the regulated subject matter").

128. Chevron U.S.A. Inc. v. Natural Res. Def. Council, Inc., 467 U.S. 837, 844 (1984) (quoting United States v. Shimer, 367 U.S. 374, 382 (1961)).

129. Id. at 866 .

130. Id. at 863-64 (" $[\mathrm{T}]$ he agency, to engage in informed rulemaking, must consider varying interpretations and the wisdom of its policy on a continuing basis."). 
a complex federal statutory scheme and state regulations it may or may not preempt.

The importance of agency expertise in applying analyses in the regulatory context on which courts have traditionally exercised independent judgment is epitomized by the review of the telephone company-cable television crossownership restrictions under the 1984 Cable Communications Policy Act. ${ }^{31}$ That inquiry's balance between the government interest furthered by the Act and the regulated parties' presumptive rights rested on detailed FCC analysis of the relevant restrictions' evolving costs and benefits over time. The agency had ultimately concluded that those provisions had "accomplished their purpose" of furthering Congress's objective of "preventing telephone companies from establishing a monopoly position in cable television service that would have precluded the growth and success of an independent cable industry." ${ }^{32}$ After the regime was struck down, the FCC reinterpreted the relevant statutory provision with explicit reference to constitutional avoidance principles ${ }^{133}$ before the entire landscape was reworked by Congress itself in the 1996 Telecommunications Act.

Where essentially empirical balancing governs a canon's application, at least, agency expertise can provide courts with the very type of information a robust analysis of regulation's impact on canonic norms would require. At the same time, the structure of agency decisionmaking claims a host of political benefits related to both oversight by the political branches and participatory input, which can further both the practical inclusion of canonic norms in decisionmaking and the reflection of majoritarian legitimacy.

If Elhauge's suggestion that independent judicial application of normative canons will force Congress to reveal its actual intent regarding the resolution of statutory ambiguity seems implausible as a descriptive matter, ${ }^{134}$ it does suggest, albeit at a higher level of generality, structuring decisions about the reconciliation of statutory goals and background canons to favor the involvement of the political branches. In that sense, agency consideration of normative canons in developing policy offers numerous advantages over independent judicial judgment. Congress has few tools, other than amendment, to respond to or inform judicial choices in interpreting statutes.

131. Cable Communications Policy Act of 1984,47 U.S.C. $\$ 551$ (2000).

132. US West, Inc. v. United States, 48 F.3d 1092, 1097 n.5 (9th Cir. 1994) (quoting In re Tel. Co.-Cable Television Cross-Ownership Rules (Further Notice of Inquiry and Notice of Proposed Rulemaking), 3 F.C.C.R. 5849, 5857-58 (1988)), vacated, 516 U.S. 1155 (1996) (remanding for questions of mootness).

133. See FCC Cross-Ownership Rules, 60 Fed. Reg. 31,924, 31,925 (June 19, 1995).

134. See supra text accompanying notes 61-63. 
Agencies, however, have more access than courts to knowledge about congressional will, through both formal means such as agency budgets, oversight hearings, and official confirmation decisions, ${ }^{135}$ and through informal means, such as frequent contact with legislators and staff. ${ }^{136}$ Perhaps more significantly, the transparent nature of administrative record building and agency decisionmaking-particularly in its formal iterations-can facilitate political oversight in a host of ways. ${ }^{137}$ The notice-and-comment procedures for formal rulemaking permit affected parties to participate in the decisionmaking process and provide Congress with information about agency action before it is final. ${ }^{1{ }^{38}}$ Judicially imposed, reasoned decision-making requirements, moreover, force agencies to take account of comments by those affected parties and to consider contrary arguments they make in reaching a conclusion, which increases a decision's transparency. Agencies might even, as Trevor Morrison suggests they should in his examination of the avoidance canon in executive branch interpretation, ensure that the theoretical capacity for legislative

135. Mark Seidenfeld, A Syncopated Chevron: Emphasizing Reasoned Decisionmaking in Reviewing Agency Interpretations of Statutes, 73 TEx. L. REv. 83, 136 (1994) ("Congress, however, retains greater controls over agency action than it does over judicial decisionmaking.").

136. See, e.g., Elizabeth Garrett, Attention to Context in Statutory Interpretation: Applying the Lessons of Dynamic Statutory Interpretation to Omnibus Legislation, IsSUES IN LEGAL SCHOLARSHIP, Nov. 2002, art. 1, at 13, http://www.bepress.com/ils/iss3/art1 ("Agency officials, who are often interpreters of statutory directives, may have the competence to perform these tasks ably because executive branch officials are usually part of the drafting process and they are actively and frequently involved in the legislative process."); Jerry L. Mashaw \& David L. Harfst, Regulation and Legal Culture: The Case of Motor Vehicle Safety, 4 YALE J. ON REG. 257, 272 (1987) (noting that agencies are in regular communication with Congress); Peter L. Strauss, When the Judge Is Not the Primary Official with Responsibility To Read: Agency Interpretation and the Problem of Legislative History, 66 CHI.-KENT L. REV. 321, 329-30 (1990) (describing the agency capacity to use legislative history for insight into statutory goals).

137. See Kenneth A. Bamberger, Regulation as Delegation: Private Firms, Decisionmaking, and Accountability in the Administrative State, 56 DUKE L.J. 377, 406-07 (2006) (discussing oversight).

138. See Lisa Schultz Bressman, Procedures as Politics in Administrative Law, 107 COLUM. L. Rev. 1749,1780 (2007) (describing the reasoned decision-making requirement "as a special form of accountability related to legislative monitoring" and citing Mathew D. McCubbins, Roger G. Noll \& Barry R. Weingast, Administrative Procedures as Instruments of Political Control, 3 J.L. ECON. \& ORG. 243, 257-58 (1987), for the connection between reasoned decisionmaking and what Bressman refers to as "fire-alarm" oversight by Congress); Gillian E. Metzger, Administrative Law as the New Federalism, 57 DUKE L.J. 2023, 2085-86 (2008) ("[B]y forcing an agency to provide notice of actions it plans to take, procedural requirements empower congressional oversight and thus reinforce such political safeguards as Congress has to offer."). 
oversight of administrative decisionmaking is actualized by notifying Congress explicitly when agencies rely on normative canons. ${ }^{139}$

Political oversight mechanisms promoting the reflection of federalism concerns in agency deliberation, too, might counsel for privileging an administrative role in incorporating, in the first instance, normative canons in statutory implementation. Just as Congress and the White House have taken specific measures to ensure that administrative decisionmaking addresses extrastatutory concerns such as the environment, ${ }^{140}$ privacy, ${ }^{141}$ and small business, ${ }^{142}$ they have, and might further, ensure consideration of canonic norms. Executive Order $13,132^{143}$ explicitly requires federal agencies, as part of notice-and-comment procedures, to consult with state and local authorities regarding the federalism implications and preemptive effect of regulations under consideration. And Congress directs the National Highway Traffic Safety Administration (NHTSA) and the FDA, two agencies whose regulations frequently implicate the scope of state tort law, to engage in exchanges with state and local agencies. ${ }^{144}$

Agencies have the capacity, moreover, to initiate deliberative and participatory processes, as well as accountability and oversight mechanisms, on their own. They might create opportunities for similar consultation with affected Native American parties, in an attempt both to elicit information and to reach an administrative result reflective of tribal concerns. Indeed, this suggestion was offered directly by the D.C. Circuit in Albuquerque Indian Rights v. Lujan. ${ }^{145}$ In that case, after holding that the particular plaintiffs lacked standing to challenge a change in the Department of Interior's interpretation of a statutory Indian hiring preference, the court suggested in dicta that the action might not survive the liberal construction canon and urged the Department to "give serious consideration to re-examining its interpretation in a forum ...

139. Morrison, supra note 94 , at 1237-39.

140. See National Environmental Policy Act, 42 U.S.C. $\$ \$ 4321-4347$ (2000).

141. See E-Government Act of 2002, 44 U.S.C. $\$ 3501$ note (2000 \& Supp. 2002) (requiring agencies to conduct a Privacy Information Assessment before "developing or procuring information technology that collects, maintains, or disseminates information that is in an identifiable form").

142. See Regulatory Flexibility Act $\$ 3,5$ U.S.C. $\$ 603($ a) (2000).

143. Exec. Order No. 13,132, 64 Fed. Reg. 43,255 (Aug. 10, 1999).

144. See Catherine M. Sharkey, Preemption by Preamble: Federal Agencies and the Federalization of Tort Law, 56 DePAUL L. REV. 227, 254 (2007).

145. 930 F.2d 49 (D.C. Cir. 1991). 
allowing," among other things, "more due process" and "more opportunity for input from interested parties."

More generally, agencies might hold open-ended hearings regarding contested normative issues, involving the range of stakeholders or experts from both inside and outside of government, as the Justice Department and the Federal Trade Commission have done in the development of their guidelines interpreting antitrust law. Or they might develop particular organizational structures ensuring independent expert oversight over the integration of extrastatutory norms of the type that may create tension with primary agency goals, such as the Department of Homeland Security's Privacy and Integrity Advisory Committee - an external federal advisory committee that oversees Department of Homeland Security (DHS) consideration of privacy implications in its policymaking. ${ }^{147}$

The notion that administrative decisionmaking might provide a forum for dialogue over the best ways to integrate statutory goals with canonic norms suggests something deeper about agency capacity to incorporate such values in decisionmaking. Indeed, agencies might not just offer important expertise regarding the appropriate balance between competing values. Rather, because an agency's general construction of a statute is frequently entwined with the question as to whether and how a presumption should apply, the agency can often define the terms of the inquiry itself. Specifically, if a canon's application is triggered by a balancing between its underlying value and the government interest as defined by the statutory goal, then an agency's choice of how to construe statutory purpose through its implementation-a judgment which itself might receive deference under Chevron-may predetermine the outcome. This phenomenon has been reflected explicitly in the context of preemption, in which some courts have explained that a "pre-emptive regulation's force does not depend on express congressional authorization to displace state law,'” but often simply on whether the agency effecting preemption "has exceeded [its] statutory authority or acted arbitrarily." ${ }^{148}$ A similar phenomenon arises with application of the constitutional avoidance and federalism canons in the Commerce Clause context, in which an agency's articulation of a limit to its

146. Id. at 59 .

147. See DHS Privacy Office, Data Integrity, Privacy, and Interoperability Advisory Committee, 69 Fed. Reg. 18,923 (Apr. 9, 2004); Kenneth A. Bamberger \& Deirdre K. Mulligan, Privacy Decisionmaking in Administrative Agencies, 75 U. CHI. L. REV. 75, 104-05 (2008) (crediting the Board for DHS's compliance with the Privacy Impact Assessment requirements of the EGovernment Act).

148. Wachovia Bank, N.A. v. Burke, 414 F.3d 305, 314 (2d Cir. 2005) (quoting Fid. Fed. Sav. \& Loan Ass'n v. de la Cuesta, 458 U.S. 141, 154 (1982)). 
authority, in and of itself, may resolve the normative canon question in the negative. ${ }^{149}$

\section{ii. The Limits of Competence}

Such capacity reflects the justifications on which Vermeule rests his defense of the case law's minority rule of administrative primacy in applying normative canons. Yet saying that agencies, as a general matter, might bring relevant strengths to the table is different from proving, as Vermeule concludes, that, by ending independent judicial canon application, " $[t]$ he interpretive complexity shunted out of the judiciary would be managed at a lower cost by agencies." 150

The fact that agency capacity may, as a general matter, offer the potential to better assess and reflect the implications of policy choices on canonic norms in some contexts does not speak to whether it actually can, and does, in any given case. Indeed, there are good reasons to think that without some form of judicial oversight such potential will not actualize.

As an initial matter, some underlying doctrines may prescribe inquiries amenable to agency competence, while others may not. Moreover, a particular agency may or may not possess expertise on the salient substantive issue, such as the policy implications for Native American or state interests. And as a factual reality, agencies in any given case may, for a variety of reasons, choose not to engage in the thorough processes or procedures on which their decisionmaking advantage is contingent, or to adjust their ultimate policy choice to accommodate competing norms.

Thorough decisionmaking is costly and the incentives for constraining agency choices to reflect the extrastatutory values are unclear, amid noisy judicial signals regarding canons' application. Moreover, agency decisionmaking may replicate the institutional barriers that hinder meaningful congressional vindication of constitutionally inspired norms the canons reflect. Bureaucrats may be no more immune to the phenomenon of "empirebuilding" ${ }^{\prime 51}$ than legislators, and the same organizational structures which help an agency's effective focus on the statutory goals with which they are charged may render them institutionally unsuited to advance the interests of those on whom federal government power impinges: states, tribes, and the subjects of

149. See infra text accompanying notes 160-168 (discussing this phenomenon in Rapanos $\nu$. United States, 547 U.S. 715 (2006)).

150. VERMEULE, supra note 70 , at 215 (emphasis added).

151. See generally Daryl J. Levinson, Empire-Building Government in Constitutional Law, 118 HARV. L. REV. 915, 932-34 (2005) (discussing literature on empire-building by bureaucrats). 
regulation. Indeed, a burgeoning literature on the organizational implications of agency structure suggests that administrative decisionmaking will be particularly resistant to secondary mandates-normative priorities distinct from, and often in tension with, an agency's existing substantive focus. ${ }^{152}$

As a result, while agencies sometimes engage in extended consideration of canonic norms, ${ }^{153}$ evidence of administrative grappling with the implications of those values for policymaking is uneven. Courts applying normative canons to reject agency interpretations repeatedly criticize agencies for ignoring extrastatutory norms ${ }^{154}$ agency decisions regarding implicated issues, such as the preemptive scope of regulations, are often conclusory and unsupported by considered analysis $;{ }^{155}$ and agencies themselves admit longstanding tendencies to exclude normative presumptions-and the values they reflect-in decisionmaking. Notably, the National Labor Relations Board conceded, just last year, that in the thirty years it has considered the question of whether its enabling act applied to the employment practices of Native American tribes, its

152. See, e.g., Jeanne Nienaber Clarke \& Daniel C. McCool, Staking Out the Terrain: Power and Performance Among Natural Resource AgenCies 4-5 (2d ed. 1996) (noting that some agencies may not easily incorporate the purposes of new legislation, even when they accord with the agency's original mission); Bamberger \& Mulligan, supra note 147 , at 83 (discussing organizational barriers to agency incorporation of secondary privacy mandates in the implementation of primary substantive statutes); J.R. DeShazo \& Jody Freeman, Public Agencies as Lobbyists, 105 CoLUM. L. REv. 2217, 2220 (2005) (citing examples of "[a]gencies frequently resolv[ing] ... interstatutory conflicts by prioritizing their primary mission and letting their secondary obligations fall by the wayside"). See generally Bamberger, supra note 137 (discussing systemic barriers to incorporating secondary goals in organizational decisionmaking).

153. See Morrison, supra note 94, at 1218-20 (providing examples of the Department of Justice Office of Legal Counsel opinions considering constitutional avoidance).

154. See, e.g., Edward J. DeBartolo Corp. v. Fla. Gulf Coast Bldg. \& Constr. Trades Council, 485 U.S. 568, 576-77 (1988) ("The Board was urged to construe the statute in light of the asserted constitutional considerations, but thought that it was constrained by its own prior authority and cases in the Courts of Appeals, as well as by the express language of the Act, to hold that [the governing statute] must be construed to forbid the handbilling involved here.").

155. See, e.g., McNellis ex rel. DeAngelis v. Pfizer, Inc., Civ. No. 05-1286, 2006 WL 2819046, at ${ }^{*} 9$ (D.N.J. Sept. 29, 2006) (declining to give preemptive effect to a rule where the reversal of prior policy of non-preemption was declared in the preamble to be "a novation, not subjected to prior public notice or comment"); Sharkey, supra note 144 (discussing the phenomenon of informal declarations of preemption); see also Morrison, supra note 94, at 1218 (noting that the FCC "has on several occasions acknowledged an obligation under Supreme Court precedent to construe a stature where fairly possible to avoid substantial constitutional questions," but that "[o]ther than the statement that Supreme Court precedent obliges the agency to employ avoidance, however, these pronouncements contain no discussion of the basis for the canon" (internal quotation marks omitted)). 
jurisprudence "has been inadequate in striking a satisfactory balance between the competing goals of Federal labor policy and the special status of Indian tribes in our society and legal culture." 156

Thus, agencies may claim particular capacity to advance the type of constitutional and structural norms that may otherwise be underenforced and unreflected, and to do so in a way that better locates policymaking in political, rather than judicial, initiative. Yet whether this potential is realized remains highly contextual, based on the doctrines and substance at issue, and the facts as they actually unfold, case by case.

\section{Operative Discretion and Judicial Limits}

\section{a. Discretion in Statutory Construction}

The type of discretion created by doctrinal frameworks for implementing normative canons offers the possibility of an agency contribution. A second source of discretion traditionally inherent in the judicial application of canons, however, suggests that any resolution to the Chevron-canons debate must reflect certain understandings regarding the limits of judicial authority.

This second cause of discretion arises from the ways in which normative canons traditionally operate in practice. Canons are only triggered if a statute reflects ambiguity about the question at issue-whether a statute has preemptive effect, has a detrimental impact on Native American tribes, or implicates serious constitutional concerns. More specifically, they are only relevant in circumstances in which there are multiple permissible ways to read the statute, and at least one of which comports with the requirements of the canon. In cases of preemption, the ensuing choice is relatively straightforward: where a statute is silent on preemption, either the negative presumption governs, in which case the state law survives, or the presumption is rebutted, and the federal statute claims preemptive effect. But in the case of the avoidance canon, there may be a variety of permissible ways to interpret the statute. Nonetheless, once it rejects a problematic construction, a court in its traditional Marbury role as independent arbiter of statutory meaning will go ahead and choose the one it believes to be best.

For example, in Buckley $v$. Valeo, ${ }^{157}$ the Supreme Court's leading decision on campaign finance reform, the Court avoided constitutional questions by adopting a detailed savings construction of the broad term "expenditure[]" to

156. San Manuel Indian Bingo \& Casino, 341 N.L.R.B. 1055, 1056 (2004).

157. 424 U.S. 1 (1976). 
cover communications only where they "advocate the election or defeat of a clearly identified candidate for federal office," and do so using "express terms" such as "'vote for,' 'elect,' 'support,' 'cast your ballot for,' 'Smith for Congress,' 'vote against,' 'defeat,' 'reject." "158 Those interpretations have governed the term's meaning since. ${ }^{159}$

The concern this phenomenon generates in the context of judicial review is evident in the Supreme Court's recent application of the avoidance canon in Rapanos $\nu$. United States. ${ }^{160}$ Rapanos arose from federal civil enforcement proceedings brought by the Army Corps of Engineers pursuant to Clean Water Act provisions requiring a permit before discharging dredged or fill material into "navigable waters." ${ }^{161}$ That term was, in turn, defined by statute as "the waters of the United States, including the territorial seas." ${ }^{162}$ The Corps's regulations had construed this language-and therefore the scope of its jurisdiction-broadly to reach, among other things, the wetlands the petitioners sought to fill: those lying near ditches or man-made drains that eventually empty into traditional navigable waters. ${ }^{163} \mathrm{~A}$ similarly broad interpretation of federal jurisdiction was struck down five years earlier in Solid Waste Agency v. Army Corps of Engineers, ${ }^{164}$ which invoked, among other grounds, both the avoidance canon and the presumption against altering "the federal-state framework by permitting federal encroachment upon a traditional

158. Id. at $43-44 \&$ n. 52 .

159. Shays v. FEC, 414 F.3d 76 (D.C. Cir. 2005) (reviewing a challenge to the Bipartisan Campaign Finance Reform Act of 2002).

160. 547 U.S. 715 (2006).

161. 33 U.S.C. $\$ 1342(\mathrm{a})(4)(2000)$; see also id. $\$ 1311(\mathrm{a})$.

162. Id. $\$ 1362(7)$.

163. More generally, the regulations construed the Act to cover, in addition to traditional interstate navigable waters, 33 C.F.R. $\$ 328.3(a)(1)$ (2004), "[a]ll interstate waters including interstate wetlands," id. $\$ 328.3(a)(2)$; "[a]ll other waters such as intrastate lakes, rivers, streams (including intermittent streams), mudflats, sandflats, wetlands, sloughs, prairie potholes, wet meadows, playa lakes, or natural ponds, the use, degradation or destruction of which could affect interstate or foreign commerce," id. $\$ 328.3(\mathrm{a})(3)$; "[ $t$ ] ributaries of [such] waters," id. $\$ 328.3(\mathrm{a})(5)$; and "[w]etlands adjacent to [such] waters [and tributaries] (orher than waters that are themselves wetlands)," id. $\$ 328.3(\mathrm{a})(7)$. The regulation defines "adjacent" wetlands as those "bordering, contiguous [to], or neighboring" waters of the United States, id. $\$ 328.3(\mathrm{c})$, and specifically provides that "[w]etlands separated from other waters of the United States by man-made dikes or barriers, natural river berms, beach dunes and the like are 'adjacent wetlands,"' $i d$.

164. 531 U.S. 159, 168-71 (2001). 
state power" 165 to reject the Corps's construction and avoid reaching the question of whether it violated the Commerce Clause.

The Rapanos plurality recognized ambiguity in the term "waters of the United States," but, citing Solid Waste Agency and the avoidance jurisprudence, concluded that the Corps's interpretation was similarly impermissible. ${ }^{166}$ Chief Justice Roberts, a member of the plurality, wrote separately to explain the scope of the decision. While Solid Waste Agency rejected the Corps's view that "its authority was essentially limitless," he made clear nonetheless that " $[\mathrm{g}]$ iven the broad, somewhat ambiguous" terms employed in the Act, the agency still "would have enjoyed plenty of room to operate in developing some notion of an outer bound to the reach of their authority." ${ }^{167}$ In other words, he suggests that, although the canons ruled out the particular agency construction before the Court, a variety of permissible options remained. Nonetheless, the plurality went on to fix a statutory definition, holding that "only those wetlands with a continuous surface connection to bodies that are waters of the United States in their own right, so that there is no clear demarcation between [the two], are adjacent to such waters and covered by the Act." ${ }^{\prime 68}$

\section{b. Systemic Limits on Judicial Authority}

This sort of discretion traditionally attendant to the independent judicial application of normative canons does nothing to further the canons' animating concerns. Not only is its exercise unrelated to the substantive values the canons reflect, but it affirmatively undermines core notions of judicial restraint in the face of other institutions more competent to resolve statutory ambiguity. To the extent that courts apply canons independently to fix a statute's meaning in their step-one analysis (or, all the more, to circumvent Chevron's framework altogether), the canon may provide a means for eluding deference and removing the policy issue from the agency's hands altogether. As such, it threatens the very sort of judicial aggrandizement at the expense of agency discretion that troubled the Supreme Court in its recent Brand $X$ decision, ${ }^{169}$ which resolved the conflict between Chevron's deferential review and another

165. Id. at 173 .

166. Rapanos v. United States, 547 U.S. 715 (2006).

167. Id. at 757-58 (Roberts, C.J., concurring).

168. Id. at 742 (plurality opinion) (internal quotation marks omitted).

169. Nat'l Cable \& Telecomms. Ass'n v. Brand X Internet Servs., 545 U.S. 967 (2005); see also Bamberger, supra note 30 , at $1294-1306$ (setting forth the problems of judicial aggrandizement that would animate the Brand $X$ holding). 
tool for applying statutes: binding judicial precedent. That decision, furthermore, raised the practical stakes of permitting canons, as a categorical matter, to trump agency statutory construction.

In Brand $X$, the Supreme Court considered whether judicial precedent should bar an agency from adopting a contrary interpretation of a statute in a form otherwise deserving of Chevron deference. Specifically, the case involved a challenge to an FCC interpretation of an ambiguous provision of the Communications Act of 1934 that conflicted with earlier judicial constructions of the Act. The Ninth Circuit rejected the Commission's new construction, relying on preexisting Supreme Court cases that seemed to embody the principle that whenever a court decision resolved a statute's meaning, that resolution would be "incorporated" into the statute itself as a form of "superstrong" stare decisis, precluding contrary constructions unless Congress itself rewrote the legislative text. ${ }^{170}$

The Supreme Court distinguished these precedents and reversed the Ninth Circuit, deciding that "[o]nly a judicial precedent holding that the statute unambiguously forecloses the agency's interpretation, and therefore contains no gap for the agency to fill, displaces a conflicting agency construction." ${ }^{171}$ On the other hand, when Congress leaves ambiguity in a statute meant for implementation by an agency, a judicial choice of one option within the zone of indeterminacy, although it would be authoritative in resolving the particular case or controversy, would be provisional, permitting the agency later to put forth a different interpretation in a manner deserving Chevron treatment.

$B$ rand $X$, therefore, suggests that applying normative canons wholesale to statutory construction (whether characterized as formal step-one analysis or the functionally equivalent independent judicial judgment) would exceed the legitimate scope of judicial authority to interpret regulatory statutes, even in the face of foundational values that conflict with the policies underlying Chevron. By using ambiguity-resolving tools to interpret legislation beyond what is necessary to ensure that agency interpretations do not impinge on canonic norms, a court fixes a statute's meaning not just in this instance, but in other contexts in which those values might play out differently. Undermining Chevron's recognition of the importance of flexibility in policymaking, such a rule would impermissibly foreclose the ability of agencies to exercise the

170. See Brand X Internet Servs. v. FCC, 345 F.3d 1120, 1130-32 (9th Cir. 2003) (holding that prior judicial construction of the Communications Act "remains binding precedent ... even in light of the FCC's contrary interpretation" (citing Neal v. United States, 516 U.S. 284 (1996))); see also Bamberger, supra note 30, at 1277-79 (describing incorporation doctrine and statutory precedents before $B$ rand $X$ ).

171. Brand $X, 545$ U.S. at 982-83. 
primary interpretive authority delegated to them by Congress, remove policy from the hands of expert administrators, and freeze its evolution in the face of changing circumstances and across context.

\section{Replacing Context for Category}

Read as a whole, then, the jurisprudence on normative canons does not reflect a uniform requirement that Congress always speak explicitly about certain important structural values. Rather, it is more accurately read as a statement that the process of shaping positive lawmaking should be structured to ensure that those values are reflected in government policy, with sensitivity to the strengths and weaknesses of the institutions involved. Moreover, it suggests an openness to altering the calculus when other institutional players, like state courts, have the capacity to compensate for deficiencies in judicial competence and resolve normative questions in ways that facilitate judicial restraint. ${ }^{172}$

Finally, it suggests that canon application is ill suited to the type of categorical resolution offered by the competing lines of Supreme Court and court of appeals jurisprudence or the claims of leading commentators. Normative canon application is often more than an inquiry into the existence of an explicit statement-the type of positive inquiry into statutory text that Chevron continues to assign exclusively to courts in its first step. Rather, it varies by context, often involves detailed analyses regarding the practical implications of choices between competing norms, and frequently leaves a great deal of discretion to those assigned with the task of statutory construction. Glossing over these realities predetermines the question, permitting the circular conclusion that canonic values must be protected in a singular manner, regardless of institutional context.

Agency capacity, too, is neither uniform in existence nor consistent in exercise. Relying entirely on generalities about administrative behavior to ensure that public policy reflects important background values means that such norms will be vindicated inconsistently, if at all.

172. See supra note 90. 


\section{FINDING A HOME FOR CONTEXTUAL APPLICATION OF NORMATIVE CANONS: RECONCILING GOALS UNDER CHEVRON'S STEP-TWO INQUIRY}

Accordingly, the canons jurisprudence and the realities of administrative decisionmaking together suggest that, while categorically placing the responsibility for protecting canonic norms on a single institution may make sense in a context in which courts in any event interpret statutes independently, canons do not, after Chevron, necessarily require the assignment of all of the discretion inherent in their application either to judges or to agencies alone. Rather, the introduction of another actor-the administrative agencies to which Chevron commends primary interpretive authority over regulatory statutes generally-might counsel a different institutional calculus: one that is sensitive to the limits that administrative law counsels for judicial discretion, to the particular capacities and shortcomings of agencies, and to the contextual nature of canon application in any particular case.

\section{A. Incomplete Beginnings}

A few scholars have taken steps toward an analysis that recognizes variation in canon application and the contextual nature of the agency contribution. In particular, Nina Mendelson has suggested that the Chevron-canons tension be resolved through canon-by-canon consideration of appropriate roles of courts and agencies. She concludes that the appropriate institutional balance for applying the presumption against preemption, even after Chevron, is found in a regime in which the canon trumps deference and courts continue to exercise independent canon application, but which also leaves judges discretion to consider a particular agency view's "power to persuade" under the analysis provided by Skidmore $v$. Swift $\&$ Co. ${ }^{173}$ the case guiding the judicial review of agency action too informal to trigger Chevron analysis. ${ }^{174}$ When resolving issues

173. Skidmore v. Swift \& Co., 323 U.S. 134, 140 (1944).

174. Under Skidmore, a reviewing court evaluates an agency's interpretation in light of "the thoroughness evident in its consideration, the validity of its reasoning, its consistency with earlier and later pronouncements, and all those factors which give it power to persuade, if lacking power to control." Id.; see also United States v. Mead Corp., 533 U.S. 218, 234-35 (2001) (limiting Cheuron's application to cases in which Congress has given the agency in question the authority to bind regulated parties with the "force of law," and if the agency has in fact exercised that authority, other agency action is reviewed under a Skidmore regime); Mendelson, supra note 63 , at 742 (" $[\mathrm{A}]$ preferable regime would not include 
like a regulation's preemptive scope, then, courts could credit agency arguments in view of "particular agency expertise." ${ }^{175}$ More recently, other prominent scholars have advanced arguments for Skidmore review of agency preemption determinations. ${ }^{176}$

This approach, while an improvement on the all-or-nothing approach of the case law, is nonetheless incomplete. Isolating the question of a canon's application under a Skidmore inquiry raises both conceptual and practical problems. Conceptually, by focusing separately on the ex post persuasiveness of the agency's argument regarding the canonic norm at issue, it suggests the severability of the normative question from the construction of the applicable statute more generally. It therefore fails to deal with the problem of incentives for the thorough and accurate integration of the canonic norm throughout agency policymaking. ${ }^{177}$ Skidmore, moreover, privileges a host of values unrelated to the canon inquiry $;^{178}$ the consistency of an agency interpretation frequently constitutes the factor that weighs most heavily in favor of respect. ${ }^{179}$

Chevron deference. A court should retain not only the ability to apply the ... presumption against preemption, but also the discretion to take account of an agency interpretation on preemption under a regime such as Skidmore $v$. Swift $\&$ Co. The court might do so when it views the interpretation as possessing particular 'power to persuade' in view of, say, particular agency expertise.").

175. Mendelson, supra note 63 , at 742 .

176. See Sharkey, supra note 44, at 491-98; Merrill, supra note 63, at 775. Sharkey argues for Skidmore respect as a means to effectuate an "agency reference model," in which the empirical data collected by an agency, and its reasoning, can "guide courts' judgments regarding the need for, and equally significantly, the present feasibility of, uniform national regulatory standards." Sharkey, supra note $\mathbf{4 4}$, at 453 . Merrill considers Skidmore analysis as a possible way to permit an apportionment of the different elements of a preemption decision - "draw[ing] upon the strengths of agencies in terms of the interpretational and pragmatic variables, while preserving the role of the courts insofar as the constitutional variables are concerned." Merrill, supra note 63, at 775; see also Brief of the Center for State Enforcement of Antitrust and Consumer Protection Laws Inc. as Amici Curiae in Support of Petitioner at 15, Watters v. Wachovia Bank, N.A., 127 S. Ct. 1559 (2007) (No. 05-1342) (arguing, with Professor Merrill as counsel of record, that "[a]gency views about preemption should receive Skidmore deference"). Professors Brian Galle and Mark Seidenfeld, too, look to Skidmore analysis as a touchstone in the review of preemption determinations, in concert with an analysis of the type of institutional capacities emphasized here. See Galle \& Seidenfeld, supra note 78, at 2001-02 (" $[T]$ he solution is that the appropriate level of deference is something of an amalgam of Skidmore and hard-look review.").

177. See Metzger, supra note 138 , at 2105 (arguing that it would be "[m]ore beneficial" to "approach the question from a perspective that emphasizes the quality of agency reasoning and explanation," such as in "hard look" review under the Administrative Procedure Act).

178. See Merrill, supra note 63 , at 776 ("[T]he Skidmore test does not focus on the variables in preemption where input from agencies would be most helpful ... [and therefore] does 
Moreover, Skidmore's unstructured inquiry places no constraintprocedural or substantive - on judicial canon application. Indeed, the few cases that have tried to replace the Chevron framework with a judicially focused inquiry that nonetheless accords agency views "substantial deference," 180 "substantial weight,"181 or "some weight," independent judgment on the matter in the categorical manner suggested by case law's majority rule, ${ }^{183}$ with all its implications for expansive, and permanent, judicial resolution of statutory ambiguity. Expressly permitting judges to consider expert agency arguments, then, while sound policy on its own terms, does little to enlist predictably the type of administrative behavior we might want, ${ }^{184}$ or to address $B$ rand $X$ concerns regarding the appropriate scope of judicial authority.

nothing to channel attention to those aspects of the preemption decision where the agency can provide the most help to the court ...."). Accordingly, Merrill ultimately advocates a sui generis standard of review in preemption cases, which might have courts "give 'significant weight' to agency views about the practical impact of diverse state rules on the implementation of federal regulatory schemes that they administer or as to which they have significant experience and expertise," accord "even more weight" when states and other interested parties have been allowed to participate through notice and comment proceedings, and exercise "independent judicial judgment" on all other relevant issues. Id. at 775-76.

179. Jim Rossi, Respecting Deference: Conceptualizing Skidmore Within the Architecture of Chevron, 42 WM. \& MARY L. REV. 1105, 1144 (2001) ("Of all the Skidmore factors, consistency seems most widely used by courts.").

180. Lawrence County v. Lead-Deadwood Sch. Dist. No. 40-1, 469 U.S. 256, 262 (1985) (reviewing an Interior Department interpretation that found that a state law governing the distribution of federal funds was preempted).

181. Medtronic, Inc. v. Lohr, 518 U.S. 470,496 (1996) (reviewing an FDA interpretation that found state common law claims preempted by the federal Medical Device Amendments of 1976); see also id. at 505 (Breyer, J., concurring) (allowing the agency a "degree of leeway"); Mass. Ass'n of HMOs v. Ruthardt, 194 F.3d 176, 182 (1st Cir. 1999) (characterizing Medtronic as according an "intermediate level of deference" to FDA interpretation).

182. Geier v. Am. Honda Motor Co., 529 U.S. 861, 883 (2000) (reviewing a Department of Transportation conclusion that state tort law would conflict with the National Traffic and Motor Vehicle Safety Act, as implemented by regulations imposing passive restraint requirements on car manufacturers).

183. See Mendelson, supra note 63 , at $740 \mathrm{n} .11$ (discussing shifting doctrinal formulations and the ultimate independent analysis applied by the Court).

184. See Metzger, supra note 138 , at 2104 ("After all, why should agencies pay careful heed to federalism concerns in interpreting statutes if courts are unlike [sic] to defer to their decisions?"). 


\section{B. A Home for Canons at Chevron's Step Two}

This Section identifies a different doctrinal framework for operationalizing canon application - one that both allows for a contextual inquiry into the type of analysis necessary and the particular agency contribution in each particular case and also permits an institutionally sensitive enlistment of the capacity of both judges and agencies. Specifically, in reviewing otherwise deferencedeserving agency constructions, the canon inquiry should be incorporated into Chevron's second-step analysis of the agency construction's reasonableness.

This proposal arises from undeveloped suggestions in a handful of outlier cases decided over the last fifteen years by the D.C. Circuit - the court most familiar with administrative law - as it has struggled to find a way to reconcile the normative canons' round peg with the Chevron framework's square hole. ${ }^{185}$ Together, they suggest a starting point for a doctrinal departure from the dominant categorical approach to the Chevron-canons question that, when developed more fully, offers an operational home for promoting canonic norms that best encourages agency potential, preserves judicial oversight, and ensures limits against judicial abrogation of agency interpretive discretion more generally.

These outlier cases-two in particular-specifically suggest one way in which placing the canons analysis at step two remedies the problem of operational discretion accorded courts under the majority rule. The analysis that builds on these suggestions in turn explores how the benefits of such a solution are far broader. At a minimum, the incentives provided by the steptwo structure can order decisionmaking to resolve important issues before they reach the judiciary, and to frame the issues in a manner that sharpens review when judges do get involved. Moreover, the tools offered by step two's reasonableness analysis can induce agencies to engage their institutional strengths more fully, draw on agencies' unique capacity as a forum for norm consideration and norm balancing, and promote a contextual assessment of norm application in any particular case.

185. Alex Tallchief Skibine has suggested the potential for exploring Chevron's second step as a venue for consideration of the Indian liberal construction canon, arguing that "the courts should hold as impermissible, under Step II of the Chevron inquiry, any agency interpretation that does not take into account the Indian liberal construction rule." Alex Tallchief Skibine, The Chevron Doctrine in Federal Indian Law and the Agencies' Duty to Interpret Legislation in Favor of Indians: Did the EPA Reconcile the Two in Interpreting the "Tribes As States" Section of The Clean Water Act?, 11 ST. THOMAS L. REv. 15, 20 (1998); id. at 28 (explaining that if an agency did not apply the canon, "chances are good that the interpretation might not be permissible"). 


\section{Placing Canons in Step Two: Suggestions from the Outlier Cases}

In $A F L-C I O \quad v \cdot F E C,{ }^{186}$ the principal case explicitly discussing the application of canons at Chevron's second step, the D.C. Circuit considered the role of the avoidance canon in reviewing a Federal Election Commission regulation requiring the "public release of all investigatory file materials not exempted by the Freedom of Information Act" at the close of an investigation into alleged election law violations. ${ }^{187}$ Appellants challenged the regulation as inconsistent with both the governing statute and the First Amendment, ${ }^{188}$ and Judge Tatel, writing a majority opinion joined by Judge Sentelle, analyzed the case under the Chevron framework. At step one, his opinion considered "the provisions at issue in context" employing both "traditional" tools for reading statutory language and purpose, and legislative history, ${ }^{189}$ and determined that the text could support a number of plausible interpretations, meaning it was "ambiguous for purposes of Chevron analysis." ${ }^{190}$ He continued, however, by considering the import of appellants' constitutional claim at step two. Weighing the government's interests in requiring disclosure against the burdens imposed on the targeted groups, he concluded the agency's construction was "impermissible because it fail[ed] to account for the substantial First Amendment interests." ${ }^{191}$

In structuring his analysis as he did, Judge Tatel explicitly rejected a longstanding circuit precedent cited by Judge Henderson in her concurrenceMichigan Citizens for an Independent Press $v$. Thornburgh ${ }^{192}-$ which had adopted the Supreme Court rule that both textual and normative canons should be counted " $[\mathrm{a}]$ mong the traditional tools of statutory construction the court must first exhaust under Chevron and its progeny." ${ }^{193}$ Michigan Citizens had in turn explicitly rejected the claims by a dissenter, then-Judge Ruth Bader

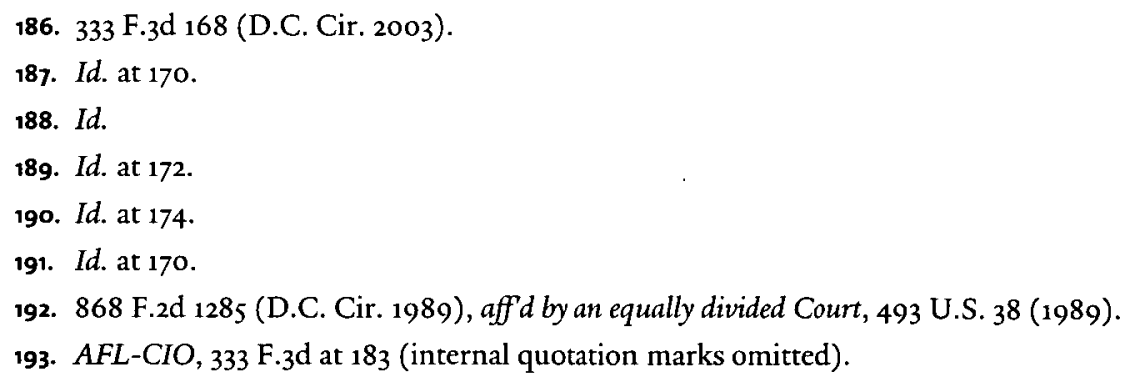


Ginsburg, that normative canons should be considered at step two's reasonableness analysis lest the important values they promote be uprooted. ${ }^{194}$

Notwithstanding Michigan Citizens, Judge Tatel - albeit several years before $B$ rand $X$ was decided-rooted his departure in concerns about the discretion a step-one approach accords judges. "[H]ere," he observed, "the statute is susceptible to more than one constitutionally permissible interpretation: As we have indicated, the Commission could tailor its disclosure policy to avoid unnecessary First Amendment infringements." 195 Yet he cautioned, "[n]either DeBartolo nor Chevron suggest that the court-as opposed to the agencyshould choose between these permissible alternatives."196 Several years earlier, Judge Sentelle had made the same point in applying the presumption against preemption, describing how canons may "constrain the possible number of reasonable ways to read an ambiguity in a statute," but not "suffice to make the intent of the statute sufficiently clear for the court to pronounce what Congress intended." ${ }^{197}$ By addressing normative canons at step two, then, the court could strike down the agency's offending construction as unreasonable while refraining from saying any more about statutory meaning, essentially

194. See Michigan Citizens, 868 F.2d at 1299-1300 \& n.6 (R.B. Ginsburg, J., dissenting) (arguing that the court should have considered the antitrust construction canon, and disagreeing with the majority's conclusion that substantive canons are no longer applicable, lest Chevron uproot a guide of such "'fundamental importance' to antitrust law administration").

195. $A F L-C I O, 333$ F.3d at 179.

196. Id.

197. Massachusetts v. U.S. Dep't of Transp., 93 F.3d 890, 893 (D.C. Cir. 1996) (assuming, without deciding, that Chevron applies, and then, under step-two analysis, concluding that the Department of Transportation interpretation was unreasonable in light of the presumption against extending preemption statutes to areas of traditional state control). Elsewhere, Judges Tatel and Sentelle have each used language that at least suggests the possibility of interpretive tools' place in step two. See PDK Labs., Inc. v. DEA, 438 F.3d 1184, 1191, 1197 (D.C. Cir. 2006) (Tatel, J.) (using the canon that "statutes written in broad, sweeping language should be given broad, sweeping application" to support a determination that the agency's construction was "reasonable"); Ball, Ball \& Brosamer v. Reich, 24 F.3d 1447 (D.C. Cir. 1994) (Sentelle, J.) (placing legislative history outside the realm of the step-one analysis and within the ambit of Cheuron's second step); $c f$. EEOC v. Arabian Am. Oil Co., 499 U.S. 244, 260 (1991) (Scalia, J., concurring) (stating, after assuming that the agency's interpretation of an ambiguous statute was entitled to Chevron deference, that "deference is not abdication," and that in light of the presumption against extraterritoriality, it was "not reasonable" to read the statute as the agency did); Rust v. Sullivan, 500 U.S. 173, 224 (1991) (O'Connor, J., dissenting) (stating that, in light of the avoidance canon, "we need only tell the Secretary that his regulations are not a reasonable interpretation of the statute"). See generally Nat'l Mining Ass'n v. Kempthorne, 512 F.3d 702, 711-12 (D.C. Cir. 2008) (treating constitutional avoidance as a basis for finding the Secretary's interpretation of an ambiguous statute "unreasonable"). 
remanding the issue, and leaving to the agency whatever interpretive discretion remained.

\section{Exploring a Step-Two Canons Analysis}

\section{a. Understanding Chevron's Second Step as a Framework for Structuring Normative Inquiry}

Incorporating normative canons into the step-two reasonableness inquiry seems the only way to reconcile those tools' continued use in judicial review with Brand $X$ 's rule that courts should not choose between alternative statutory constructions that are otherwise permissible and, more broadly, with both Chevron's fundamental policy of preserving flexibility in administrative policymaking and the canons' caution toward judicial restraint.

Yet at first glance, integrating normative canons into Chevron's step-two reasonableness analysis might seem incongruous, rather than appear as a path to reconciling the values underlying the two regimes. For example, permitting a court to consider at step two whether a particular canon should result in the rejection of an agency policy as unreasonable sits uncomfortably with a formal understanding of Chevron's framework as a means to vindicate legislative intention. Such an inquiry clearly does not mesh with an understanding of step two as an inquiry into the breadth of leeway a fictional Congress would have "wanted" to delegate to an actual agency by means of a specific statute. Moreover, judicial consideration of normative canons at step two fits awkwardly with the traditional characterization of Chevron's two-step process as a means to divide a court's sphere of substantive inquiry (limited to the stepone inquiry into statutory meaning) from that of agencies (constituting the agency interpretation to which deference is usually accorded at step two). ${ }^{198}$ For a growing consensus of prominent administrative law scholars, courts' role at step two should be conceived principally as procedural, and the reasonableness inquiry akin to that provided under the Administrative Procedure Act's prohibition against policymaking that is "arbitrary and capricious." 199

198. See generally Patricia M. Wald, Judicial Review in Midpassage: The Uneasy Partnership Between Courts and Agencies Plays On, 32 TULSA L. REv. 221, 244 (1996) ("Chevron was basically meant as a device to enhance the power of agencies vis-a-vis the courts and Congress ....").

199. Richard J. PierCe JR., i ADMINISTRATIVE LAW TrEatise $\$ 7.4$, at 444 (4th ed. 2002); Ronald M. Levin, The Anatomy of Chevron: Step Two Reconsidered, 72 CHI.-KENT L. REv. 1253, 1268 (1997) (" $[T]$ he second step of the Cheuron formula was intended to be a direct counterpart to the arbitrariness test that courts had traditionally applied ...."); M. Elizabeth Magill, 
Yet as we have seen, these two conceptual lenses for understanding Chevron's divide provide little guidance regarding the appropriate place for the consideration of canonic norms exogenous to a statute. The disarray in the case law reflects the indeterminacy that arises from trying to answer the "canons" question either through the lens of congressional intent, or from conclusory assertions as to whether normative tools of statutory construction are essentially judicial on the one hand or administrative on the other.

If these more formalist understandings of Chevron's two-step division fail to inform the Chevron-canons debate, then an understanding of the framework's practical operation proves more helpful. Specifically, firmly rooted in the language of the Chevron decision itself is an understanding that its two inquiries involve different kinds of decisionmaking: positive analysis at step one; normative - on the part of both courts and agencies - at step two. Such an understanding underlies the Chevron decision's basic allocation of interpretive authority between courts and agencies in resolving statutory ambiguity and provides a framework for structuring decisionmaking as well with regard to canonic norms.

Chevron's first inquiry into whether Congress has directly spoken on an issue centers on an essentially positive inquiry as to legislative meaning. Accordingly, as the Brand $X$ decision explicates, resolution of the statutory issue at step one is appropriate only when it can be said Congress's instructions mandate a singular reading. Such resolution, accordingly, forecloses the issue as a matter of precedent going forward.

Chevron's second step, by contrast, concerns normative judgments. It assigns to agencies primary interpretive authority to make policy choices permitted by the scope of the statutory delegation, informed by substantive expertise, political sensitivity, and a granular contextual analysis of the "full understanding of the force of the statutory policy in the given situation."'20o But it also assigns to courts the task of bringing to bear a host of extrastatutory norms relevant to the reasonableness of the agency determination.

Many of these extrastatutory values are, to be sure, manifest through procedural requirements. Yet even those elements reflect a variety of norms of constitutional dimension-norms relating to the rule of law, separation of powers generally, and nondelegation itself-by promoting accountability,

Step Two of Chevron v. Natural Resources Defense Council, in A GUIDE TO JUdicial AND Political Review of Federal AgenCies, supra note 14, at 85, 99 ("Chevron step two should be explicitly understood to incorporate a 'reasonableness' requirement drawn from the arbitrary and capricious case law.").

20o. Chevron U.S.A. Inc. v. Natural Res. Def. Council, Inc., 467 U.S. 837, 844 (1984) (quoting United States v. Shimer, 367 U.S. 374, 382 (1961)). 
transparency, and thorough decisionmaking through elements of hard look review adopted, in large part, in the context of judicial assessments of agency action under the Administrative Procedure Act. ${ }^{201}$ Agencies must engage in "reasoned decisionmaking," supplying explanations for their decisions that demonstrate consideration of all of the important aspects of the issue, reflect the evidence before them, and explicitly assess alternate policy choices. ${ }^{202}$ They must further demonstrate that they have engaged in processes that permitted and considered input by policy stakeholders, and exhibit at least some degree of decision-making transparency, allowing for meaningful oversight by Congress and review by courts. ${ }^{203}$ Moreover, consistent with the preAdministrative Procedure Act doctrine set forth in the 1943 decision SEC $v$. Chenery Corp. ${ }^{204}$ courts evaluating an agency action will consider only the grounds clearly and contemporaneously invoked by the agency, ensuring the constitutionally grounded norm that "accountable agency decision-makers, not merely courts and agency lawyers, have embraced the grounds for the agency's actions, and that the agency decision-makers have exercised their judgment on the issue in the first instance." ${ }^{205}$ Finally, the Supreme Court's rare categorizations of agency interpretations as unreasonable also rest on extrastatutory values - norms against standardless discretion in the exercise of government power ${ }^{206}$ and the delegation of authority to private parties. ${ }^{207}$

201. See, e.g., Smiley v. Citibank (S.D.), N.A., 517 U.S. 735,742 (1996) (implying that if a line of credit were "arbitrary [or] capricious" it would thereby be "disentitled to deference under Chevron"); Chem. Waste Mgmt., Inc. v. EPA, 873 F.2d 1477, 1482 (D.C. Cir. 1989) (explaining that the arbitrary-and-capricious claim is "functionally a Chevron step two contention that [the agency]'s interpretation of the stature is unreasonable"); Levin, supra note 199, at 1268. But see Cont'l Air Lines, Inc. v. Dep't of Transp., 843 F.2d 1444, 1452 (D.C. Cir. 1988) (arguing that while Chevron step two may be "closely akin to plain vanilla arbitrary-and-capricious style review," it would be inappropriate "to import wholesale that body of law and apply it in a conceptually distinct arena").

202. Motor Vehicle Mfrs. Ass'n of U.S. v. State Farm Mut. Auto. Ins. Co., 463 U.S. 29, 52 (1983).

203. See Bamberger, supra note 137 , at $406-07$ ("[T] he transparent nature of administrative record building and agency decisionmaking ... facilitates accountability in a host of ways."); Schultz Bressman, supra note 138 (describing the reasoned decision-making requirement).

204. 318 U.S. 80 (1943).

205. Kevin M. Stack, The Constitutional Foundations of Chenery, 116 YALE L.J. 952, 958-59 (2007).

206. See AT\&T Corp. v. Iowa Utils. Bd., 525 U.S. 366, 388 (1999) (finding unreasonable an agency interpretation that failed to contain any "limiting standard, rationally related to the goals of the Act"); $c f$. Whitman v. Am. Trucking Ass'ns, Inc., 531 U.S. 457, 485 (2001) ("The EPA may not construe the statute in a way that completely nullifies textually applicable provisions meant to limit its discretion."). 


\section{b. The Reasonableness Inquiry and Norm Balancing}

Understood in this manner, reasonableness analysis seems a more sympathetic home for canon application. Indeed, far from simply accommodating the integration of normative canon analysis, the traditional approach of the step-two reasonableness inquiry actually provides the tools instrumental in furthering its goals in the regulatory context. The inquiry preserves judicial capacity for meaningful review, enlists administrative strengths, and provides a single, adaptive framework that can accommodate the variety of normative canons courts employ, the variability in their application, and changes in their formulation over time.

\section{i. Preserving Judicial Capacity}

As an initial matter, step two's case-by-case assessment permits courts to determine whether a canon's doctrinal formulation in the particular context at issue leaves room for administrative input. Where a canon makes clear that a norm-impinging choice is the type of politically charged decision only appropriate when reached through the strictures of congressional decisionmaking-for example, the super-strong clear-statement rule for expanding American colonial power by abrogating Native American treaty rights - courts can continue to strike down such agency choices by direct application of the canon. Moreover if, regardless of the procedures used, the agency decision-making process fails to overcome organizational hard-wiring against extrastatutory norm protection - for example, if the outcome simply neglects to account for canonic values-courts may reject the choice as unreasonable. In both circumstances, however, any remaining discretion in construing the statute is returned to the agency.

\section{ii. Enlisting the Strengths of Administrative Decisionmaking}

At the same time, step two's robust inquiry into an agency's actual decision-making process offers a way, on the one hand, to promote the effective integration of the substantive values underlying canons by agencies, and on the other hand, to permit a judicial decision as to whether expertise and political deliberation point to a satisfactory resolution of norm balancing without judicial intervention.

207. See Iowa Utils. Bd., 525 U.S. at $388-89$ (finding that the statute forbade delegation of regulatory authority to telecommunications companies). 
To be sure, agency lawyers might, in a legal brief, be able to marshal familiarity with a statute at issue to provide a particularly informed defense of an agency's completed choice. But step two's rejection of such ex post justifications, and its inquiry into contemporaneous agency processes, provide means for asking whether the benefits of agency perspective were actually employed: Did the agency use formal processes when reaching its conclusion as to the extent to which its decision implicated canonic norms? Did it inform Congress when deciding to adopt an interpretation that pushed the limits of their power? Did it provide a forum that promoted input from, deliberation by, or negotiation with, interested parties? Did it hold hearings or involve independent or external expert oversight mechanisms? Did it consider constitutional, federalism, and Native American concerns not just in the balancing inquiry governing whether a canon should apply, but also when reaching the understanding of the statutory goals that may determine the weight of the federal interest itself? In short, in this particular case, were the particular forms of administrative decisionmaking through expertise, representation, and accountability - modes of inquiry inaccessible to judges used in ways that would make a court comfortable concluding that the institutional reasons traditionally counseling the use of prophylactic canons were overcome sufficiently to displace the default rule?

By using the step-two reasonableness inquiry in this manner-by defining the types of decision-making processes conducive to norm accommodationcourts can alter administrative behavior prospectively. Under current case law, agencies face uncertain signals regarding the consideration of canonic norms. A regime that conditioned substantive judicial outcomes on specific administrative norm-accommodation processes, however, could take advantage of the fact that expertise, political deliberation, and organizational structure are not static but can be altered by external incentives. ${ }^{208}$ Indeed, this reflects the lessons regarding the positive effect of robust judicial enforcement of the National Environmental Protection Act's environmental impact assessment

208. See, e.g., Jacob E. Gersen, Overlapping and Underlapping Jurisdiction in Administrative Law, 2006 SUP. CT. ReV. 201, 212-13 (criticizing views of expertise as "static and exogenous," and exploring how "the assignment of jurisdiction can be used to create incentives for agencies to invest in the development of expertise"); see also Sharkey, supra note 155 , at $256-58$ (suggesting through the use of deference as a "penalty default rule" to ensure "full compliance with the congressional and executive mandates designed to ensure robust dialogue and debate among state and federal stakeholders, courts would force agencies, at a minimum, to account for any divergence between their stated purposes to promote uniformity and enhanced safety, and the consequences flowing from evisceration of state common-law causes of action"). 
requirement on administrative decisionmaking ${ }^{209}$ and the changes wrought by Chevron itself on modes of agency policymaking. ${ }^{210}$

This change in incentives is important in two ways. First, it encourages agencies to increase the frequency with which they consider canonic norms in the first instance. At the very least, sequencing decisionmaking in this manner places the initial balance of statutory and nonstatutory goals in the hands of decisionmakers who may be in a better position to bring technical expertise and political insight to that assessment. When that inquiry results in an interpretation that implicates constitutional norms, courts will retain the opportunity to assess whether, given the agency's application of expertise or sensitivity to political input in the particular case, normative canons counsel otherwise. Yet when that inquiry adopts a constitutionally protective outcome, the agency judgment itself has achieved the task of "guard[ing] against premature or unnecessary constitutional adjudication."211 Moreover, the likelihood is increased that public policy will reflect the interests of states, tribes, and governed parties, as well as structural constitutional limits, in those cases in which agency action is never reviewed by a court.

Even more significantly, such a case-by-case reasonableness review provides incentives for qualitative changes in the agency contribution to questions of norm elaboration. If Sunstein's vision of uniform and consistent judicial application of strong clear-statement canons were realized ${ }^{212}-$ assuming that such a thing were possible, given the discretion inherent in the

209. Although the National Environmental Policy Act's initial focus on decision processes permitted widespread resistance from many agencies and resulted in widely inconsistent implementation, see Allan F. Wichelman, Administrative Agency Implementation of the National Environmental Policy Act of 1969: A Conceptual Framework for Explaining Differential Response, 16 NAT. RESOURCES J. 263, 296-300 (1976) (studying the implementation of the National Environmental Policy Act across numerous different federal agencies), it is now considered by many in and out of agencies to have successfully "[i]nstitutionaliz[ed] [e]nvironmental [v]alues in [g]overnment," Serge Taylor, Making Bureaucracies

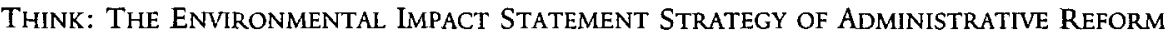
251 (1984). This result is attributed to robust judicial oversight. See Wichelman, supra, at 296-300.

210. See E. Donald Elliott, Chevron Matters: How the Chevron Doctrine Redefined the Roles of Congress, Courts and Agencies in Environmental Law, 16 VILL. ENVTL. L.J. 1 (2005) (describing how Chevron shifted the locus of administrative decisionmaking from lawyers to policy experts).

211. Meredith Corp. v. FCC, 809 F.2d 863, 872 (D.C. Cir. 1987) (requiring the agency to consider the constitutional avoidance argument raised by the party in adjudication under review).

212. Sunstein, supra note 56, at 2607-10 (arguing that substantive canons of statutory construction will engender decisional predictability within the executive). 
application of such directives - then agencies would simply be incentivized to parrot predicted judicial canon application to interpretive problems, despite the fact that normative canons embody inexact default presumptions intended to correct for institutional shortcomings that agencies may not face. An administrative apparatus that limited its normative analysis to court-tracking modes of decisionmaking would, as Jerry Mashaw argues, "effectively set itself up as the sole arbiter of the constitutionality of congressional action"213 without adding anything to the political or expert dialogue.

By contrast, contextual step-two review reflects not only the notion that some constitutional norms that courts might otherwise underenforce because of institutional concerns may still constrain agency choices, ${ }^{214}$ but also that agencies might arrive at conclusions that would depart from independent judicial canon application. Sometimes those views will reflect deliberative and analytic methods that might balance norms more accurately. Recognizing the latter argument suggests that a contextual review can ameliorate the most perverse effects of judicial canon application, especially in the case of constitutional avoidance. The judicial reconstruction of a statute, under the guise of restraint and respect for legislative supremacy in unlikely or strained ways "that its drafters did not anticipate ... [and] may not have preferred,"215 is neither a model of separation-of-powers protection nor a sound means for settling on good public policy. Permitting agencies to make the case that the goals of the statute - construed in light of the complexity of implementation, or

213. Jerry L. Mashaw, Between Facts and Norms: Agency Statutory Interpretation as an Autonomous Enterprise, 55 U. TORONTO L.J. 497, 505 (2005).

214. See generally Lawrence G. SAger, Justice in Plainclothes: A Theory of American CONSTITUTIONAL PRACTICE 84-128 (2004) (suggesting that certain constitutional principles required by justice are judicially underenforced, yet nonetheless may impose affirmative obligations outside the courts on legislatures, executives, and citizens generally); MARK Tushnet, TAKing the Constitution AWAY from the Courts (1999) (arguing that the Constitution is self-enforcing through the political process); Frank I. Michelman, Welfare Rights in a Constitutional Democracy, 1979 WASH. U. L.Q. 659, 684-85 (arguing that the Constitution secures rights to minimum welfare, but leaves the enforcement of those rights to legislatures and executives). But $f$. MiCHAEL A. BAMBERGER, RECKLESS LEGISLATION: HOW LAWMAKERS IGNORE THE CONSTITUTION (2000) (documenting the trend of legislators ignoring or rejecting the independent constitutional obligations of the political branches).

215. Schauer, supra note 19 , at 74 ; see id. at 83 (suggesting that these are in fact the total set of instances in which canons would have any bite); see also JERRY L. MASHAW, GREED, CHAOS, and Governance: Using Public Choice To Improve Public LaW 102-05 (1997) (relying on a simple public choice model to suggest that statutory misconstruction intrudes on legislative prerogatives more than statutory invalidation on constitutional grounds). 
the outcomes of participatory or oversight-enhancing process ${ }^{216}$-point strongly in the direction of rebutting a canon's presumption (in the case of the avoidance canon, prompting courts to resolve the ultimate constitutional question) serves as a constraint on labored statutory constructions and all that they involve.

\section{iii. Step Two as an Adaptive Framework for Accommodating Variability}

Finally, step two provides a single framework that can accommodate contested and contingent jurisprudential choices regarding the meaning and implementation of background norms. The set of normative canons is neither closed nor static. Moreover, as explored in Part III, the application of each can vary by context. These applications evolve, and the strength and continuing vitality of individual canons are matters of vigorous theoretical debate.

A step-two contextual analysis is, in an important sense, agnostic with regard to these background issues. It provides a means for applying canons in the review of administrative regulation however they operate-as clearstatement rules, presumptions, or simply as tie-breakers. Whatever the strength of a canon in the relevant context, the reasonableness analysis provides both incentives for administrative accommodation of the underlying value in the first instance and the opportunity for meaningful judicial review. It thus accommodates the breadth of canons however they are formulated contemporaneously by courts, and adapts should those formulations change over time.

\section{Possible Critiques: Considering Costs}

Integrating the normative canons analysis into Chevron's reasonableness inquiry, however, would likely increase certain decision costs-indeed, it is specifically intended to do so. Replacing a categorical assignment of institutional authority with a contextual approach that enlists multiple participants complicates the analysis. Courts would no longer proceed directly to an independent resolution of statutory ambiguity, as in the case of the majority rule, or invoke Chevron's on-off deference regime, as with the

216. Indeed, the adoption of costly processes may signal the strength of the agency belief in its interpretation. See Matthew C. Stephenson, A Costly Signaling Theory of "Hard Look" Judicial Review, 58 ADmIN. L. REv. 753, 755 (2006) ("[T]he court can reason that the expert government decisionmaker's willingness to produce a high-quality explanation signals that the government believes the benefits of the proposed policy are high."). 
minority. They would be required to assess the agency's decision process, as well as its substantive outcome. Agencies, in turn, would face incentives to complicate their own decision processes, integrating methods and procedures for considering a second set of norms that may be tangential, if not at odds, with the primary policy concerns around which their structures and personnel are organized.

To the extent that more complicated decisionmaking serves to reduce error costs and promote more accountable and legitimate norm balancing, those decision costs serve a purpose. Yet an objection might be made that abandoning categorical rules for more complex standards increases the opportunity for manipulation. Chevron, for all of its warts, has proven an important tool for cabining judicial discretion to second-guess agency policy choices in at least an important subset of cases. Independent judicial review of constitutional issues, moreover, still serves as a final bulwark against the excesses of bureaucratic power. Might diluting the categorical nature of each doctrine permit judges to smuggle their substantive policy preferences into Chevron's otherwise deferential framework or loosen constraints against administrative aggrandizement?

A realistic assessment of the alternatives suggests just the opposite. At present, courts possess significant leeway to manipulate canons to reach desired substantive ends. Indeed, the variability with which canons are applied - and the unpredictability as to whether they will be applied at all-has rendered courts vulnerable to criticism from both sides of the political spectrum. ${ }^{217}$ At the same time, agencies engage canonic norms haphazardly, freed from meaningful constraint by unpredictable standards of review. A striking new study by William Eskridge and Lauren Baer underscores the ways in which the flowering of doctrines permitting judicial review outside Chevron's framework expands the potential for unchecked judicial discretion. ${ }^{218}$ In $53.6 \%$ of the relevant cases decided since 1984 , the Court "does not apply

217. Compare Richard H. Fallon, Jr., The "Conservative" Paths of the Rehnquist Court's Federalism Decisions, 69 U. CHI. L. ReV. 429, 471-72 (2002) (arguing that conservative Justices have invoked preemption to achieve substantive goals), with Michael S. Greve, Federal Preemption: James Madison, Call Your Office, 33 PEPP. L. REV. 77, 80-81 (2005) (accusing liberal Justices of applying the presumption against preemption to achieve their substantive goals).

218. See William N. Eskridge, Jr. \& Lauren E. Baer, The Continuum of Deference: Supreme Court Treatment of Agency Statutory Interpretations from Chevron to Hamdan, 96 GEO. L.J. 1083 (2008). 
any deference regime at all," but instead "relies on ad hoc judicial reasoning" of the sort involved in the independent judicial interpretation of statutes. ${ }^{219}$

By contrast, placing the canons inquiry in Chevron's second step offers the possibility of more, rather than fewer, decision-making constraints. Agencies face incentives to integrate important norms in policymaking. Judges are told to channel more cases through Chevron's frame, favoring norm-reflective agency solutions and constraining judicial resolution of issues outside the canons' domains. To the extent that courts would smuggle substantive reasonableness concerns into their independent application of canons, they are told to do so with greater candor and accountability in the step-two inquiry; and to the extent that agencies fail to reflect canonic norms sufficiently, courts are in a position to serve in their traditional safeguard role. Indeed, structuring judicial review in such a manner offers a means for reducing decision costs to both agencies and courts over time, as courts develop a kind of blueprint for the application of various normative canons in different contexts.

Moreover, rejecting categorical approaches for a step-two solution might create a forum for sharpening and rationalizing judicial articulation of the canons more generally. When courts, in the traditional manner, apply canons independently as part of a broader independent construction of the statute, variability in doctrinal articulation may have lower stakes. Despite shifting canonic articulations and inconsistency in the reasoning about the choice between them - frequent characteristics of judicial decisions applying canons a court can nonetheless arrive at the resolution of competing norms it thinks best in each case.

By admitting a role for agencies, however, a step-two solution suggests that courts should be clearer about which aspects of an interpretive decision point to which canonic formulation, which types of agency behavior might contribute to the analysis, and what the governing standard suggests about both the limit of judicial interpretive authority and the remaining space for administrative policymaking. The resulting case law might not only aid in the more consistent use of canons in the context of Chevron review, but also assist in rationalizing canon doctrine more broadly, fostering the general judicial capacity for systemic uniformity in the protection of important values.

\section{CONCLUSION}

Recent scholarship has heralded the unique contribution agencies can make to questions of public norms. "Well-informed institutions, like agencies," can

219. Id. at 1090 . 
"cut away issues that should not be a matter of dispute," narrowing the scope of disagreement that must be resolved by other institutions. ${ }^{220}$ Their capacity for reasoned and expert judgment about the practical consequences of policy choices, their sensitivity to evolving political context, and their ability to provide a forum for input by, and dialogue among, a range of stakeholders offer a particular "interpretive voice"221 with "distinctive interpretive methodologies" 222 situated at the frontier between facts and norms. In this way, administrative "norm-entrepreneurship" through statutory interpretation "can enrich our national discourse about fundamental values" ${ }^{223}$ in ways distinct from courts, who, of all the institutions in the project of governance, may "know[] the least and [be] least able to provide a forum for wide-ranging dialogue and jurisgenerativity. ${ }^{224}$

Yet at the same time, the administrative enterprise, at its core, rests on vigilance against ill-constrained decisionmaking. Most significantly, it embodies a "profound ... reliance on the courts as the ultimate guardian and assurance of the limits set upon executive power by the constitutions and legislatures."225

Chevron's second-step reasonableness analysis provides a framework for a context-sensitive, case-by-case application of normative canons that can enlist these comparative strengths of both courts and agencies. It provides incentives for agencies to incorporate normative concerns in policymaking in the first instance, to resolve issues by means of expertise, politics, and dialogue before they ever reach courts, and to find norm-protective solutions in the variety of agency interpretations that might never be reviewed. It further offers agencies the opportunity to make the case, based on their unique familiarity with practical and political facts on the ground, that a statute's mandate points strongly in the direction of a norm-impinging construction; and thus, for example, that courts should proceed to decide a constitutional question directly, rather than strain the bounds of Congress's intent. Finally, it ensures that, whatever the final determination on the normative issue, residual discretion to construe regulatory ambiguity remains with regulators, rather than courts.

220. Eskridge \& Schwartz, supra note 100, at 2625.

221. Ellen P. Aprill, The Interpretive Voice, $3^{8}$ LOY. L.A. L. REV. 2081 (2005).

222. Mashaw, supra note 213 , at 499.

223. Eskridge \& Schwartz, supra note 100, at 2625.

224. Philip P. Frickey, (Native) American Exceptionalism in Federal Public Law, 119 HARV. L. REv. 433, 485 (2005) (discussing institutional capacity in the context of Native American law).

225. Louis L. JafFe, Judicial CONTROL of Administrative ACtion 321 (1965). 
At the same time, the step-two solution leaves courts the power to apply normative canons independently when administrative decisionmaking offers little advantage for norm balancing, while also allowing them to vindicate regulatory decisions if agencies exercise their capacity in ways that ameliorate institutional barriers to accurate norm application. As such, the solution exploits the variety of strengths of the administrative state to promote goals of both normative canons and Chevron: a preference for political decisions and judicial modesty, flexibility in regulatory implementation, and the reflection of constitutionally inspired values in policymaking. 